\title{
The informal economy and its impact on tax revenues and economic growth. The case of Peru, Latin America and OECD countries (1995 - 2016)
}

\author{
Guillermo Boitano \\ Pontificia Universidad Católica del Perú \\ gboitano@pucp.pe \\ Deyvi Franco Abanto \\ Universidad de Lima \\ deyviabanto@gmail.com
}

El objetivo principal de la investigación es determinar el tamaño de la economía informal en Perú, América Latina y los países de la OECD, así como estimar el impacto de la economía informal en la recaudación tributaria y el crecimiento económico. Para alcanzar el objetivo, la aproximación se realiza a través de modelos MIMIC. Los resultados principales muestran que el tamaño promedio de la economía informal como porcentaje del PBI en el Perú es 37.4\%, en los países de América Latina es de 34\%, y de 19.83\% para los países de la OECD; es decir, un poco menos de la mitad del promedio de América Latina.

Palabras clave: economía informal, gestión estratégica, crecimiento económico, impuestos, América Latina

The main goal of the research will be to determine the size of the informal economy in Peru, Latin America and OCDE countries as well as to estimate the impact of the informal economy on tax revenues and the economic growth. To achieve the goal, the approach is made through MIMIC (multiple-indicator and multiple-cause) model. The main results show that the estimated average size of the informal economy as a percentage of the GDP in Peru is $37.4 \%$, in Latin America is 34\%, and in OCDE countries is $19.83 \%$, which represents less than half of the Latin America average.

Keywords: informal economy, strategic management, economic growth, taxation, Latin America 


\section{Introduction}

For the last 20 years, Peruvian economy has maintained a sustained growth of $5 \%$, unlike Latin America (3.8\%) and OECD (2.7\%). It has been one of the few economies to overcome the 2008 crisis with a GDP growth. Accordingly, Peru's tax revenues (17\% in 2015) have also grown during the last 20 years, but not at the same magnitude as the OECD (35\%) and Latin American countries (22\%) (OECD, 2016). However, in spite of being one of the most solid economies in Latin America, there is a complex phenomenon: the informal economy, with negative impact on both the economy and society. For the purpose of this paper, we will use the definition of informal economy proposed not only by De Soto (1986), who understands this phenomenon as a source of entrepreneurship that seeks income outside the formal economy due to the pressures of government's regulation, as well as the one proposed by Buehn, Dell'Anno, and Schneider (2012), Schneider and Colin (2013), and INEI (2016), that describes the informal economy as the set of productive activities subject to tax and social contributions, consciously hidden from the tax authorities due to tax burdens. Besides, in this paper, the theoretical concepts will be based on what was developed by Voicu (2012).

Reducing informal economy is fundamental not only for tax collection purposes -as tax base could be increased and tax evasion reduced-, but also for Peru's economic growth. However, focusing only in tax purposes, the tax structure in Peru and Latin America is dominated by indirect taxes, which results in low redistributive capacity and higher inequality. On the contrary, in OECD countries, the system is progressive meaning concentrated in direct taxes. Concentrating on direct taxes improves welfare and equality but is only possible by absorbing the informal economy and reducing informal employment (OECD, ECLAC, CIAT \& IDB, 2016).

Most of the phenomenon is analyzed from the economic perspective, even though informal economy is also relevant within the management area. For instance, Godfrey (2011) and Mc Gahan (2012) agreed that the informal economy is a "new frontier for management scholarship and research (Godfrey, 2012, p. 233)» because these businesses structures work in an environment where management theories could be stressed. Informality does not imply the business does not look for returns, lack of strategies and avoids competition and an ethical dilemma (Godfrey, 2011). Not including these activities in the management analysis and research is to look at half of the picture (Mc Gahan, 2012). Complementing the idea, Bruton, Ireland and Ketchen (2012) added that although the informal economy is an important topic due to its great participation in the economy (especially the emerging ones) there is little research about it and many possibilities to increase the knowledge on the topic when expanding the areas of study beyond the features and character of the informality. Bruton, Ireland, and Ketchen (2012) indicated that "the informal economy is the final frontier of the management domain (p. 2)». Additionally, Welter, Smallbone, and Pobol (2015) indicated that the informal sector is associated with the informal entrepreneurship that offers empowerment, emancipation and participation to activity. The entrepreneurial spirit, then, can empower people in a similar way to the first discussion on the duality between the informal and formal economy (Welter, Smallbone \& Pobol, 2015). Moreover, Darbi and Knott (2016) described the SNP (Strategic Networking Practices) between companies in an 
informal economy around four interconnected topics: 1) open communication, 2) fraternal substitution, 3) commitment, and 4) naturalization. It shows the degree to which tacticians can bring non-economic and «non-rational» personal and social considerations to the strategic decisions they make on behalf of the organization; thus, the total comprehension of the strategic methods of informal businesses is improbable without considering these types of stimuli (Darbi \& Knott, 2016). These findings contribute to profound awareness of the social linkage perspective on strategic networks, and to the use of SAP (strategy as a practice) in strategic activities, options and practices aimed at individual professionals immerse into a social environment (Darbi \& Knott, 2016). After proposing four possible policy options. Besides Williams (2015) showed that, if nothing is done, the existing undesirable effects on formal entrepreneurs, informal entrepreneurs, customers, and governments will remain. There is no evidence that formal sector deregulation addresses informal entrepreneurship, whereas the eradication of informal entrepreneurship would result in governments suppressing and destroying the entrepreneurial effort and the corporate culture they actually try to foment; thus, the transformation of informal entrepreneurship into a formal one is shown as the most possible political alternative (Williams, 2015). The current method in which direct limits are used to enhance detection and escalate penalties is still quite perfectible as there is a much broader set of tools - not mutually exclusiveavailable to address informal entrepreneurship (Williams, 2015). Mukherjee (2016) indicated that the informal economy is huge and will persist in time. Indeed, depending on how it is defined, it could be the most dominant model of economic organization and therefore calls for an appropriate policy response that can promote equitable linkages between formal and informal economies. It rejected the idea that informal firms act as a weak substitute for formal firms (Mukherjee, 2016). Finally, Mathias, Lux, Crook, Autry, and Zaretzki (2015) pointed out that while property and social policies serve to permit formal activity and decrease informal activity, structural and financial policies limit formal activity and rise informal activity.

In sum, the main goal of this research will be to determine the size of the informal economy in Latin America and OCDE countries to estimate its impact on tax revenues and the economic growth, and to analyze the structural changes needed to increase formality. Especially attention will be paid in the case of Peru, trying to elaborate recommendation to better understand its informal economy and how to integrate it into the national formal economy.

\section{Definition of informal economy}

An open definition rather than a concrete and closed one is needed due to three reasons: 1) a singular and arbitrary definition could leave out many characteristics and not reflex the current phenomenology, 2) a precise definition could end up with an inadequate mechanism of measurement, and 3) different countries have informal economies with different characteristics (Eilat \& Zinnes, 2000). Bovi and Dell'Anno (2009) recognized that the shadow economy has not a unique and agreed definition, nor does it have a common name. 
Smith (1987) defined the informal economy as a non-formal one that does not consider in the national accounts. Ogunc, Fethi, Yilmaz, and Gokhan (2000) mentioned that a "parallel» or "shadow» economy are terms used to refer to it although no formal agreement exists about a definition. Schnider (1986), cited by Ogunc et. al. (2000), defined the informal economy as the set of activities that add value and could be accounted for the national income but are not registered. Smith (1994), as cited by Ogunc et. al. (2000), considered the production of goods and services that are not included in the GDP. Bagachaw (1995), cited by Ogunc et. al. (2000), points that it should be divided into three categories: 1) the informal sector, 2) the parallel markets, and 3) the black markets. Eilat and Zinnes (2000) mentioned that the term «informal» has been mainly used to refer to small and artisan activities usually carried out in developing countries. Other terms recognized by Eilat and Zinnes (2000) are "hidden» and "underground" economy, used to refer to tax avoidance; the "parallel» and "black» economy, refer to illicit activities; the "unofficial» and "unrecorded" economy refer to non-recorded activities in the national statistics; and "shadow» economy (following Tanzi (1982)) points out activities in which the government has not intervened or endorses.

Frey and Schneider (2001) recognized terms such as «informal», «unofficial», «irregular», «parallel», «second», «underground», «subterranean», «hidden», «invisible», "unrecorded», "shadow», "moonlight», and "black». There is not a unique definition and all of them depend on the objective of the analysis. Thus, the normal way of treating the informal economy is relating it to an unrecorded activity in the GDP. However, under this assumption, activities such as household activities and tax avoidance are not included in the statistics because they are not value-added activities (Frey \& Schneider, 2001). Finally, Frey and Schneider (2001) specified that the informal economy cannot be confused with illegality (activities against the Law such as drug distribution, for instance (p. 7442)).

According to Gylys (2005) there are several terms used for defining the informal economy, most of which are related to negative aspects of the phenomenon. What matters more is the fact that the attention is set more in the name than in the fundamentals of the economic phenomenon (Gylys, 2005). Hence, in the economic life, there are five different aspects to consider: 1) the official or regulated economy, 2) the unofficial or unregulated economy, 3) activities not fulfilling with official requirements, 4) registered activities, and 5) unregistered activities. The first three are linked to formality of the economic activity while the last two relate to the possibility of registration of the activity (Gylys, 2005).

According to Brambila and Cazzavillan (2010), the terminology «informal economy» was first used by Hart $(1973 ; 1990)$ to explain the characteristics of the labor market in Africa. In addition, Brambila and Cazzavillan (2010) also mentioned all the different ways to measure it. This definition is used by the International Labor Organization (ILO) and implies that informality is characterized by a high incidence of poverty, inequality and vulnerability compared to the normal labor deficit standard.

Wan Jie, Huam, Rasli, and Thean Chye (2011) summarized several definitions of the informal economy based on its causes and taxonomy to better understand the concept and to reduce the degree of misconceptions. Webb, Bruton, Tihanyi and Ireland (2013) defined the informal economy as "economic activities that occur outside of formal institutional boundaries, but which remain within informal institutional boundaries for large segments of 
society. Given this definition, informal economy activities are technically illegal yet are not antisocial in intent (p. 1)».

\section{Theoretical approach to the informal economy}

Although Frey and Weck (1983) indicated that there is a deficiency of a theoretical structure to specify the connection between the private sector, the government and the informal sector to determine the main causes and effects of the informal economy, the later research foster a framework for the phenomenon. Thus, Wilson (2011) indicated that there are three ways to view the informal economy: 1) the dualist approach, which considers the informal sector as an underdeveloped one, where activities are undertaken by low skilled migrants and the lower skills of the informal workers (2012); 2) the structuralist approach, which looks for the connections between informal and formal economy as the last one takes advantage of the first one, following the inner character of the capitalism: looking for more competitiveness Chen (2012) ; and 3) the legalist approach, that conceives the informal economy as a product of a mercantilist government: the way for new entrepreneurs to avoid bureaucratic regulations and succeed in the market. According to Chen (2012), the cause of this last approach is the "hostile legal system (p. 5)». Finally, Chen (2012) included the so-called voluntarism approach, according to which informal economy exists because entrepreneurs openly want to evade taxation and, therefore, they must be forced to become formal to avoid the inequitable competition.

Galiani and Weinschelbaum (2011) recognized three stylized facts about informality: 1) small businesses are more probable to operate informally, 2) unqualified people are more likely to work informally, and 3) workers that are not head of the house are more likely to work informally in comparison to the head of the house. They then used these facts to develop a model that clarified the behavior of firms in terms of formal or informal work, and the corresponding behavior of the labor force and households. Thus, Galiani and Weinschelbaum (2011) proposed as a policy that "governments should not consider only labor demand but also labor supply when tackling informality (p. 837)» in addition to the government needs of enhancing the role played by household in the phenomenon.

McGahan (2012) indicated that management researchers have become more interested in studying the informality but there are problems related to both the collection of data and the use of a conceptual definition. Informal activities such as the buses that pick-up people at regular intervals and in specific places in Nairobi and Los Angeles are good example for informal economy structures. In fact, for McGahan (2012) the informal economy is decisive, so he points out:

studying informal activity yields important insights for mainstream theories of management, pointing to areas of new theorizing on the boundaries of the firm, diversification, dynamic capabilities, absorptive capacity, property rights, governance, stakeholder theory, disruptive technology, innovation, and organizational legitimacy. I argue that research on this sector is not only an opportunity for management scholars but, also essential to the continued relevance and vitality of management as a discipline (p. 12). 
According to Webb et. al. (2013), most of the research about the informal economy was centered on phenomenological aspects rather than theoretical ones. Since researchers in areas such as entrepreneurship and management have become more interested in the informal economy, a new theoretical framework is needed to analyze the phenomenon (Webb et. al., 2013): institutional theory, motivation-related theories, and resource allocation theory are the used ones. In the case of institutional theory, the idea is to analyze how the institutional setting influence entrepreneurship in the informal economy. The motivationrelated theories help to understand and structure the reasons why individuals become informal. And the resource allocation theory shows how strategies are set up to take advantage of opportunities in a resource-constrained scenario (Webb et. al., 2013).

In the same line, Gibbs, Mahone, and Crump (2014) tried to examine three theories "culminating in the development of a contextual framework that suggests appropriate theory selection for informal economy entry decision (p. 33)». These theories could help policymakers to better understand the phenomenon and increase the theoretical knowledge about the informal economy. The approach of Gibbs, Mahone, and Crump (2014) is based on the integration of contextual factors (socio-spatial variations), entry typologies (necessity-based versus opportunity-driven), external structural factors (structuralist, neoliberal, and post-structuralist). Factors such as values, customs, culture, cognitive variables, and social norms are not considered into the analysis and they should be included in future research. In this line, Achua and Lussier (2014) analyzed the informal business sector in Cameroon in three subgroups based on surveys: 1) streetwalker entrepreneurs, 2) street corner entrepreneurs (both driven by necessity) and 3) street owner entrepreneurs (driven by opportunity). Policies that sustain and encourage informal entrepreneurs at a local level would be jointly valuable, with more than half of those starting out as need-driven entrepreneurs progressing to opportunity-driven entrepreneurs form part of the formal economy (Achua \& Lussier, 2014). This shows up the necessity for policy variations to support entrepreneurs in the informal economy rather than continuing ignoring them as most governments do.

\section{Main causes of informality}

Studies on the subject cannot explain the existence of this phenomenon, although there are several ones that would explain its birth. In general terms, some authors point out that the main causes are linked to income inequality, poverty, unemployment, economic growth and economic crises. Other authors consider that causes are more linked to the excessive regulation introduced by governments and a high tax burden. Within the subject of excessive regulation, some authors place special emphasis on social and labor regulation (social security contributions, vacations, etc.). Another reason frequently mentioned is the so-called social contract or social agreement established between a government and the country's population, emphasizing in the concept of tax morale. Institutionalism understood as the transparency of institutions and governments, as well as the corruption and how laws and regulations are applied, are added as other causes of informality. Finally, education and behavioral causes are also considered as a relevant element to understand why informal agents stay in informality. The causes of informality are summarized in Table 1 : 


\begin{tabular}{|c|c|}
\hline $\begin{array}{l}\text { Economic Causes (income inequality, poverty, } \\
\text { unemployment, economic crisis, economic } \\
\text { growth) }\end{array}$ & $\begin{array}{l}\text { Elgin and Oztunali (2014); ILO and Hart (1972); } \\
\text { Tokman (1984); Wan Jie at. al. (2011); Webb, Ireland } \\
\text { and Ketchen (2014) }\end{array}$ \\
\hline Tax Burden and Regulations & $\begin{array}{l}\text { Abid (2016); Bird (2014); Eilat and Zinnes (2000); Frey } \\
\text { and Weck (1983); Loayza (1997); Nagac (2015); Tokman } \\
\text { (1992); Wan Jie et. al. (2011) }\end{array}$ \\
\hline Jobs and Social Regulations & $\begin{array}{l}\text { Bid (2012); Eilat and Zinnes (2000); Ognuc et. al. } \\
\text { (2000); Williams (2015) }\end{array}$ \\
\hline Social Agreement and Tax Morale & $\begin{array}{l}\text { Eilat and Zinnes (2000); Filippin, Fiorio and Viviano } \\
\text { (2013); Frey and Weck (1983); Haslinger (1985); Ognuc } \\
\text { et. al. (2000); Torgler and Schneider (2007) }\end{array}$ \\
\hline $\begin{array}{l}\text { Institutionalism (transparency, corruption, and the } \\
\text { application of laws and regulations) }\end{array}$ & $\begin{array}{l}\text { Aruoba (2010); Bird, Martinez-Vasquez and Torgler } \\
\text { (2008); Bologna (2015); Bovi and Dell'Anno (2009); } \\
\text { Davoodi and Grigorian (2007); De Soto (1990); Djancov } \\
\text { (2002); Elgin and Oztunali (2014); Elgin (2010); Elgin } \\
\text { and Garcia (2011); Feige (1997); Johnson (1997); Mou- } \\
\text { mouras and Rangazas (2016); North (1990); Ognuc } \\
\text { et. al. (2000); Choy, and Thum (2003); Schneider and } \\
\text { Buehn (200); Torgler and Schneider (2007); Webb, } \\
\text { Ireland and Ketchen (2014); Wei (1997) }\end{array}$ \\
\hline Investment in Self-Education & Petrescu (2016) \\
\hline Imitative Behavior (like herd behavior) & Semboja (2001) \\
\hline
\end{tabular}

Source: authors.

\section{Main consequences of informality}

In a similar way that with the causes, the consequences of this phenomenon are numerous. The effects on economic, social and tax policies are highlighted by informal economy: the greater the degree of informality, the less effective the social and economic policies become (ant-inflationary policies, fiscal expansion policies, fight against poverty etc.). Also, lower level of tax collection is achieved, affected not only by the lower tax compliance per person but also by the lower tax base. There are also effects on the labor market, specifically in terms of jobs creation, labor costs, and the skills and productivity of the labor force that operates in the informal sector, all of which have an impact on the wealth of the population and the labor regulation. Some authors emphasize the effect of the informal sector on the market, specifically on the competition between formal and informal companies, considered disloyal as informal companies don't comply with regulations, artificially maintaining lower cost structure. On the other hand, it is recognized that companies operating in the informal sector tend to be firms with a limited technological capacity and innovation due to, among other factors, the restriction of funding sources and trained labor, which leads to a reduced level of productivity and the limitation of value-added. In sum, informal economy ultimately effects negatively on economic growth of a country. The main consequences of informality are summarized in Table 2: 
Effects Fiscal Policies, Social Expenditures and taxes collection
Bovi and Dell'Anno (2009); Enste and Schneider (1998); Frey and Schneider (2001); OECD et. al. (2016); Loayza N. (2007); Loayza N. (2016); Loayza, Serven and Sugawara (2009); Ogunc et. al. (2000); Williams, Horodnic and Burkinshaw (2016)

Cespedes (2015); Chattopadhyay and Mondal (2016); Frey and Schneider (2001); La Porta and Shleifer (2008); Loayza N. (2007); Loayza N. (2016); Loayza, Serven and Sugawara (2009); Milner and Rudra (2015); Ogunc et. al. (2000)

Bovi and Dell'Anno (2009); Farrell (2004); Gokalp and Lee (2016); Ogunc et.al. (2000)

Effects on the General Productivity (factor productivity), the Level of Technology and the Value Added

Effects on the Economic Growth
BID (2010); Elgui and Birinci (2016); Loayza N. (2007); La Porta and Shleifer (2008); Loayza N. (2016); Loayza, Serven and Sugawara (2009); Pathak and Xavier-Oliveira (2015); Williams, Horodnic and Burkinshaw (2016)

BID (2010); Cespedes (2015); Eilat and Zinnes (2000); Elguin and Birinci (2016); Loayza N. (2007); Loayza N. (2016)

Source: authors.

\section{Formalization reforms and their results}

BID (2010) showed the effect of flexible tax regulation and the existence of subsidies on the informal economy. These issues are further explored by Gómez and Morán (2012), who analyzed the development of taxation policies in Latin America and showed that spending in collecting institutions is higher than in developed countries (OECD). Feld and Schneider (2010) found that, in OECD countries, the level of dissuasion to neutralize informality did not work well. BID (2012) found that flexibility in tax regulations is better since greater coercion does not dissuade informality. However, Gómez and Morán (2012) showed that despite the progress made in reducing the informal economy due to the implementation of policies to formalize economic agents, yet informality remains with high costs in terms of tax revenue. Joshi, Prichard and Heady (2014) analyzed the diverse ways in which governments promote formalization and taxation of informal. There is a belief that taxing informal firms serves to raise money; however, there is a negative aspect related to the high cost of collecting and monitoring the process. Besides, taxing informal firms raises issues like coercion and corrupted behavior from the tax officials. As Joshi, Prichard and Heady (2014) said, the main reason that leads informal firms to pay taxes is the promotion of a tax culture in a country. About the mechanisms used by governments to formalize and include informal activities into taxation, the most used is VAT or indirect taxation (Joshi, Prichard \& Heady, 2014).

Other ways to incorporated informal firms in the tax base are enhanced enforcement and compliance, tax rewards, tax discounts, withholding taxes, and presumptive taxes. Nevertheless, all these alternatives have shown several problems such as the creation of complicated tax systems and costly processes of collection and monitoring, as well as 
unfairness problems. Even though more research is required, Joshi, Prichard and Heady (2014) show that there are fewer incentives to promote a formalization and taxation reform on the side of the politicians and tax officials. Tax evasion is not the main reason for becoming informal: avoiding regulations, the complexity of the tax system, and the cost of formalization are probably more important reasons (Joshi, Prichard \& Heady, 2014). Many times, as indicated by the authors (2014), an agent becomes informal due to the lack of skills and illiteracy (what is called the absence of capacity) and, therefore, is an involuntary movement. In this case, a formalization program should include not only the adaptation of the tax system to the characteristics of the informal firms but also topics related to property rights and dispute resolutions. The interaction between the informal sector and the government in terms of information (communication about the benefits of being formal), credibility (government fulfilling its commitment), and coordination (reform including most of the informal sector) must be addressed when working towards formalization (Joshi, Prichard \& Heady, 2014)

\section{How to measure the informal economy}

There are two groups of methods: direct and indirect. In the first one, surveys are most used. In the second one, several methodologies co-exist: the official participation rate of labor or the employment approach, the income and expenditures approach, the tax fraud estimation and tax auditing approach, the demand of money or monetary approach, the transaction approach, the total electricity use, the modified total electricity-based approach, household electricity use, and the MIMIC and SIMIC models (Andrei, Stefanescu \& Oancea, 2010; Eilat, \& Zinnes, 2000; Frey \& Schneider (2001); Frey \&Weck, 1983; Hernandez, 2009; Ogunc et. al 2000); Smith (1987) used another way to measure the informal economy: using household purchases from informal vendors. While the advantage of this method is that buyers are willing to disclose the information, the disadvantage is the differentiation the buyer has to do between formal and informal vendor.

The lack of interested in the causes and reasons for becoming informal (Frey \& Weck, 1983) complicates the measuring of informal economy. Although there are many methods to measure the informal economy, Hernandez (2009) recognized that measuring it is still a problem due to both the lack of a unified definition and the lack of information.

\section{Measuring the informal economy in Peru: application of multiple-indicator and multiple-cause models}

A multiple-indicator and multiple-cause model (MIMIC) derivative from the structural equations modeling is used in this research to measure the informal economy. This model incorporates the causes and consequences of this economic phenomenon into a single indicator that encompasses all the characteristics of the informal economy. It is important to remember that, in the case of Peru, a previous measurement was done by Hernandez (2009), who decided to use the currency demand approach under which "the informal sector or hidden economy refers to all activity that adds value but is not taxed or registered, and consequently is beyond official channels of measurement, as mentioned by De Soto 
(1986) and Loayza (1996) (p. 86)». Hernandez (2009) indicated that the currency demand approach (the excessive use of currency) has been criticized due to "the sensitivity of the results to the assumptions of the model (p. 86)». Hernandez (2009) concluded that the share of the informal economy on the Peruvian GDP is about $44 \%$ to $50 \%$, between 2000 and 2005, which is a result that could be greater if other activities like the illegal ones are included. In addition, Machado (2014), uses the MIMIC methodology to estimate the size of the informal economy for the years 1980-2011, his results fluctuate between $30 \%$ and $45 \%$ of the GDP, his study uses as causes and indicators the variables tax rates, inflation, GDP per capita, tax evasion rate and net primary enrollment rate. Unlike Torgler \& Schneider (2007) who also use the same methodology, Machado (2014) does not use institutional and macroeconomic variables to create the size of the informal economy.

In the case of the MIMIC models, Goldberger (1972) pointed out that Structural Equation Models (SEM) are widely used in behavioral, social, and economic studies to analyze structural relationships among variables. Some of them may be latent (unobservable) and SEM cover a wide variety of models and methods for multivariate analysis. Breusch (2005) indicated that because the informal economy cannot be observed, therefore it should be estimated. Thus, Breusch (2005) used a MIMIC model to measure the informal economy. Breusch (2005) recognized that the model has been used in the factor analysis of psychometrics and, at the beginning, it was used by Zellner in 1970 and Goldberger in 1972 (Breusch, 2005). In the case of the informal economy, Frey and Weck-Hannemann were the pioneers of using MIMIM models in 1984 (Breusch, 2005). After that, in 1988, Aigner, Schneider y Ghosh used a refined model called DYMIMIC (because of the use of lagged variables) (Breusch, 2005). Further, in 1999 Gyles modified again the model to include timeseries concepts such as unit roots and cointegration (Breusch, 2005). In their research, Giles and Tedds (2002) presented a Dynamic MIMIC called DYMIMIC (Breusch, 2005). Brambilia and Cazzavillan (2010) used the MIMIC model to measure informal economy because they considered that this type of model overcomes the problems of other methods by avoiding restrictions on the available information and using several variables.

Acock (2013) argued that modeling structural equations offers the ability to use multiple indicators for each latent variable and isolate it from each measurement of the error, thus eliminating it for each latent variable assigned. Besides, the power of the prediction given by the measurement of the error is assumed variable (a random error) and as such has no explanatory power (Acock, 2013). The results are estimates of the trajectory coefficients that would generally be larger than if no error was assumed in the predictors, as assumed with the traditional regression models. The trajectory analysis part of the model is called structural model and shows the theoretical causal links between the latent variables.

The MIMIC model identifies economic and social phenomena through the relationships between the variables of their causes and consequences, which is a necessary aspect but not sufficient. For a MIMIC model to be useful, stronger theoretical justification is needed. The use of indicators of the model is shown in the section called "causes and consequences (indicators)" located above. Figure 1 shows the relationship between the observed variables (indicators and causes) and the latent variable (size of the informal economy), which is not directly observed but inferred through observed variables 
directly measured. Thus, the MIMIC model is divided into two equations: 1) the structural model and 2) the measurement model.

$$
\eta=\gamma^{\prime} x+c \quad(\text { Eq. } 1)
$$

Figure 1. Proposed MIMIC Model

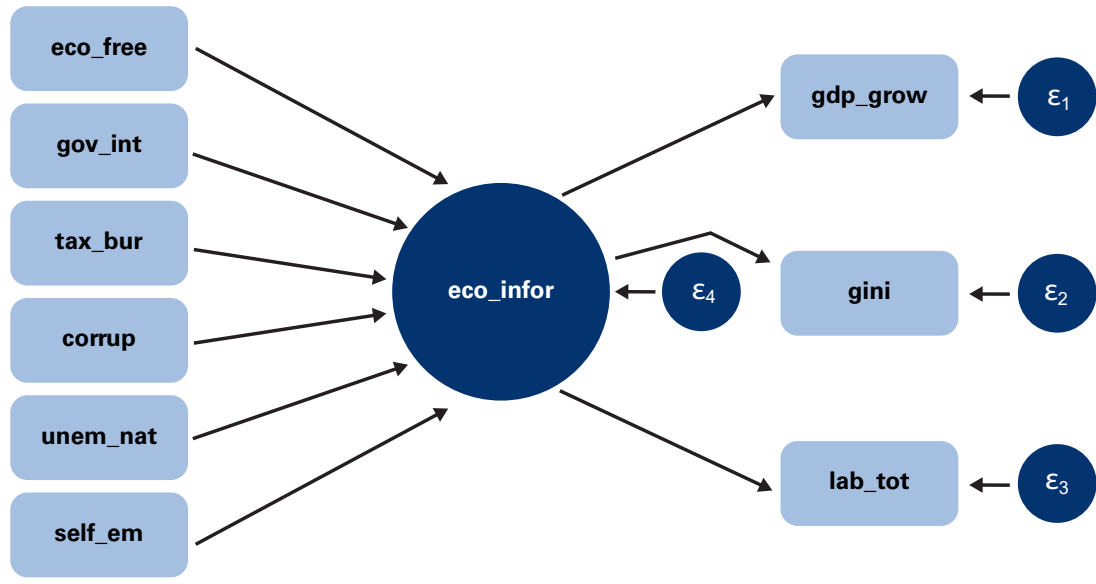

Equation 1 shows the latent variable $\boldsymbol{\eta}$ which is linearly determined by a set of exogenous causal factors. $x$ is the vector of causal variables, $\gamma$ is a scalar vector and $c$ is the term of structural perturbation. Equation 2 is linked to the set of selected indicators.

$$
\gamma=\lambda \eta+\xi \quad \text { (Eq. 2) }
$$

Where $\gamma$ is the vector of the indicators, $\lambda$ is a vector of load factors to represent the magnitude of the expected change for a unitary change in the latent variable $\boldsymbol{\eta}$. The measurement error term is $\xi$. The set of relationships between indicators and causes are simultaneous, which directly influences the size of informal economy over time.

To estimate the parameters, the MIMIC model is executed through the maximum likelihood model that adjusts the distributions of the variables and obtains its parameters. The prediction of the parameters of the latent variable only gives a trend index of the magnitude of the informal economy. To obtain the exact size as a percentage of the GDP, a second step must be performed to transform the latent variable. This procedure is called comparative evaluation and was proposed by Dell'Anno and Schneider (2009). This transformation is applied to calibrate the index. The procedure requires an initial or base year. For this research, the base year will be 1995, due to the equivalence of the data for all the countries of the study.

With equation 3 we can perform the calibration procedure:

$$
c \frac{\eta}{G D P_{T}}\left(\frac{\eta_{T}^{*}}{G D P_{T}} * \frac{G D P_{T}}{\eta_{t}}\right) \frac{G D P_{T}}{G D P_{t}}=\frac{\eta_{t}}{G D P_{t}} \quad \text { (Eq. 3) }
$$

$T$ would be the base period (1995) and $t$ the corresponding year, $\eta^{*}$ is the latent variable of the base year and $\boldsymbol{\eta}$ is the slope of each year. This procedure is applied to each country in order to obtain the size of informal economy as a percentage of GDP.

To estimate the magnitude of informal economy we use the maximum likelihood method with a special specification called Satorra-Bentler adjustment. This is done to improve 
chi-square statistics of the goodness of fit. In the case of Satorra-Benter, an estimation in maximum likelihood for non-normal variables can be done because it compensates for the non-normality of the variables to obtain a robust estimate. The method is described as a correction of distributions of non-normal variables.

Satorra and Bentler (1994) develop the correction of the value of regular chi-square for non-normality that requires the estimation of a scale correction factor (c). This reflects the amount of average kurtosis that distorts the test statistic in the data being analyzed. The chi-square value of goodness of fit for the model is divided by the scale correction factor to obtain the so-called Satorra-Bentler chi-square (SB). Normality tests are applied to check the use of Satorra-Bentler with the variables both separately and as a whole.

After explaining the detail of MIMIC model estimation, the results are summarized in Appendix A. The indicators are statistically significant although the same significance is not found in the case of all the causes. Beyond the significance analysis, the economic analysis and interpretation of signs become the most important matter. Based on the premises, MIMIC model 3 is chosen because variables fulfill the economic theory and satisfy the relations among the variables and the informal economy.

Among the causes we have the economic freedom index that is significant and related negatively to the latent variable; the government integrity index not significant but fulfilling the negative relationship with the informal economy; the significant tax burden index and its positive and proportional relationship -the higher the tax burden, the greater the informal economy; the significant self-employment rate and its positive relationship as its growth indicates higher unemployment and therefore a transfer in the informal employment; tax revenues are not significant but their relation is negative, because the lower the tax collection, the greater the informal economy; and finally, as self-employment, unemployment is also directly proportional to informal economy, with greater presence of the latent variable.

Indicators are affected by the dimension of the informal economy. Thus, the Gini coefficient is significant, and it shows a positive relationship with informal economy (the greater the inequality, the greater the latent variable); the labor freedom index is not significant, but its relationship is negative as a lower labor freedom means a higher informal employment; GDP growth is significant, but with a positive relationship. Hassan and Schneider (2016) took the GDP variable as a reference and associated it with -1. This modification is called "reduction ad absurdum» which is based on the negative relationship of informal economy with GDP growth that is fulfilled for developed countries (OECD). However, this research found that this variable has a positive relationship in Latin American countries.

We apply the Generalized Method of Moments (GMM) to observe the impact of informal economy on economic growth and tax collection, while identifying the relationship between the dependent and the instrumental variables. The method is appropriate because informal economy has many causes and consequences that relate to each other. Hayashi (2000) indicated that the most critical assumption made for the OLS model is the orthogonality between the error term and the regressors: without it, the OLS estimator is not reliable. Since in many important applications the orthogonality condition is not satisfied, it is essential to be able to deal with the endogenous regressors (Hayashi, 2000). 
The estimation method called the Generalized Method of Moments (GMM), which includes OLS as a special case, provides a solution (Hayashi, 2000). In the frame of this research, the assumption of strict exogeneity does not apply for the model presented because informal economy affects many other variables outside the model and requires instrumental variables pertinent to the correlated (endogenous) variables with the error term. To comply with the GMM assumptions, the model must be linear in compliance with the model proposed by Hayashi (2000).

- $\quad$ Assumption 1. $\gamma_{i}=z_{i}^{\prime} \delta+\varepsilon_{i} \quad(i=1,2, \ldots, n)$

Where $z_{i}$ is an L-dimensional vector of regressors, $\delta$ is an L-dimensional vector of coefficients and $\varepsilon_{i}$ is an unobservable error term.

- Assumption 2. Stationary Ergodic, where $x_{i}$ is a K-dimensional vector that refers to the vector of instruments and let $w_{i}$ be the unique and non-constant elements of $\left(y_{i}, z_{i}, x_{i}\right)\left(w_{i}\right.$ is jointly stationary and ergodic) as mentioned by Hayashi (2000).

- Assumption 3. Orthogonality condition, all variables $\mathrm{K}$ in $x_{i}$ are predetermined in the sense that they are orthogonal to the error term:

$\in\left(x_{i k}, \varepsilon_{i}\right)=0$ for all $i$ and $\mathrm{K}(\mathrm{K}=1,2, \ldots, \mathrm{K})$

$$
\in\left(w_{i} *\left(y_{i}-z_{i}^{\prime} \delta\right)\right)=0 \text { and } \in\left(g_{i}\right)=0 \text { where } g_{i}=x_{i} * \varepsilon_{i}
$$

Assumption 3 is equivalent to the strict exogeneity $\in\left(\varepsilon_{i}\right)=0$, where the instruments are not correlated with the error term.

Torgler and Schneider (2007) and MEF (2016) used the Generalized Method of Two-stage Moments (G2SM) due to the high endogeneity presented by the variables that cause informality. This method corrects problems of endogeneity and includes instrumental variables accomplishing a better explanation of the variables that have a high correlation.

Hayashi (2000) deals with this problem estimating more than one equation jointly by GMM. After using GMM in a single equation it is necessary to follow a few more steps to arrive at a multiple equation system. This is because the multiple equations GMM estimator can be expressed as a simple equation GMM estimator by properly specifying the matrices and vectors comprising the simple equation GMM formula. This being the case, it can be developed the GMM large sample theory of multiple equations almost off the platform.

Hayashi (2000) considered that the gain of dominating the GMM multiple equations is considerable. Under conditional homoscedasticity, it is reduced to the efficient estimator of the instrumental variable of complete information, which in turn is reduced to the three-stage least squares (3SLS) if the set of instrumental variables is common to all equations. If it is further assumed that all regressors are predetermined, then 3SLS is reduced to seemingly unrelated regressions, which in turn is reduced to multivariate regression when all equations have the same regressors.

- Assumption 1. Linearity: there are $\mathrm{M}$ linear equations, each of which is a linear equation as a simple GMM.

$y_{i m}=z_{i m}^{\prime} \delta_{m}+\varepsilon_{i m}(m=1,2, \ldots . ., M ; i=1,2, \ldots, n)$

Where $n$ is the size of the sample, $z_{i m}$ is the dimensional vector $L_{m}$ 
of regressors, $\delta_{m}$ is the conformable coefficient vector and $\varepsilon_{i m}$ is an n-unobservable term in the $m$-th equation. The model will not make any assumptions about the interaction correlation or the correlation between the errors $\left(\varepsilon_{i 1}, \ldots, \varepsilon_{i m}\right)$. Besides no a priori constraints are applied on the coefficients of different equations. That is, the model does not involve restrictions of cross-equations on the coefficients.

- Assumption 2. Stationary ergodic: $w_{i}$ are unique and non-constant elements of $\left(y_{i 1}, \ldots y_{i M}, z_{i 1}, \ldots, z_{i M}, x_{i 1}, \ldots, x_{i M}\right) .\left[w_{i}\right]$ is stationary and ergodic. This assumption is stronger than assuming that ergodic stationarity is satisfied for each system equation. Even if $\left\{y_{i M}, z_{i M}, x_{i M}\right\}$ is stationary and ergodic for each equation $m$, it does not necessarily strictly follow that the major process $\left\{w_{i}\right\}$, which is the union of individual processes, is (jointly) stationary and ergodic. In practice, the distinction is somewhat blurred because equations often share common variables.

- Assumption 3. Orthogonality condition: The orthogonality conditions for the system of equations $\mathrm{M}$ are only a collection of the orthogonality conditions for individual equations (this is already checked for simple GMM equations).

Using Stata (2016), the procedure for the 3SLS estimation is based on the conditions of moment $E(Z \mu)=0$. The 3SLS estimator can be used to estimate the parameters of an equation of a system of structural equations. Also, with the 3SLS estimator, it is not needed to specify the structural relationship between all endogenous variables. It is needed to specify only the equation in which the interest is centered and simply assume relationships of reduced form between the endogenous regressors of the equation of interest and the exogenous variables of the model. If the complete system of structural equations is needed to be specified, assuming that the model is correctly specified, estimates that are more efficient can be obtained using 3SLS estimating all equations together.

To verify that the instruments used in GMM and GMM 3SLS are valid, the Hansen test is applied; to prove the over-identification, the probability has to be greater than 0.05 . To estimate the results of these models, the results of MIMIC 3 (Appendix A) were used and the transformation was then performed as a percentage of GDP.

\section{Results, conclusions and recommendations}

The final model to estimate the dimension for informal economy was the MIMIC 3 showed in Appendix A, and the results are found in Appendix B and Appendix C. The same analysis was performed by Adame and Tuesta (2017) to study the impact of informal economy on both institutional variables (corruption control, government efficiency, tax collection and state effectiveness) and macroeconomic variables (self-employment, GINI, unemployment rate and GDP growth). More results are shown in Appendix D.

According to the present research, the estimated average size of informal economy as a percentage of the GDP for Latin America is 34\% while, in the case of the OCDE countries, it is $19.83 \%$, a little bit less than a half of the Latin American average. The difference between those groups of countries is due to institutional efficiencies and 
the economic development of each country. The country with the biggest informality in America Latina is Peru, with $37.4 \%$ of the GDP for 2016; in the case of the OCDE countries, it is Turkey with $29.75 \%$ for the same period time. Moreover, the Latin American country with less informality is Uruguay with $14.47 \%$ while in the OCDE countries is Denmark with $12.84 \%$, both for 2016 .

In Hassan and Schneider's results for 2013, the dimension of the informal economy for Peru $(60.9 \%)$ is approximately less than twice the estimated in the present research. The $17.3 \%$ estimation made by the INEI (2016) shows a figure which is approximately onethird of the number gotten by Schneider. Finally, this research shows proportion which is a bit less than the double of the INEI's estimation, although the trend is the same in both cases (INEI and the present research). The countries with larger informal economy according to Hassan and Schneider (2016) are Bolivia (66.04\%) and Honduras (72.41\%) followed by Mexico (31.19\%) and Greece (39.39\%). A possible explanation for the big number in Hassan and Schneider's results is the fact that they included in their model the demand of money as an indicator with the premise that an excess of demand over supply is due to informality, but it may be also explained by the existence of illicit activities that demand cash.

The results indicate that for Peru, Latin America and OECD countries, the tax collection has been negatively affected due to the dimension of the informal economy. In the case of Latin America, the policies applied to reduce the informal sector have resulted in an average reduction from 34\% to 31.4\% between 1995 and 2016. In contrast, for OECD countries, it remained at $20 \%$ throughout the years of study. In both cases, it can be inferred that policies to reduce informal economy such as reducing taxes and eliminating economic barriers to become formal have not been successful. These results opened new lines of research to find out the motivations to stay in the informal economy and to question the insertion into formality.

For Latin America, De Soto (1980) statements on the informality as a source of entrepreneurship are confirmed since the GMM 3SLS estimation shows a positive impact of the informal economy on the economic growth. The opposite happens in the case of OCED countries, where a negative effect could be found. For both Latin America and OCED countries, the informal economy harms the amount of collected taxes.

Although the informal economy is present in all countries, it is greater in the developing ones and the fixed effect in each country is persistent. Thus, solutions must not be the same for all countries and must consider the differences in cultures and idiosyncrasy. Policies such as barriers reductions for formalization or tax reductions are not solutions by themselves in isolation. The institutional framework (including the government) is an important factor to increase or decrease the informal economy. If institutions are not interested in being more efficient, transparent and committed to people's welfare, it is less probable that the informal economy could be reduced. The institutional issue must be addressed definitively considering the elimination of corruption at all levels of the economy. In the same line, Laws and regulations must not only be clear to prevent unequal application but also must be fulfilled regardless of who the subject is. Moreover, the self-employment and unemployment are directly related to informal employment, which absorbs what formal employment could not recruit. The Gini coefficient is an important indicator because a 
country with higher inequality would probably have a bigger informal economy.

The controversy about MIMIC models is well-known. Although to better improve the goodness of fit, after getting the slope of the informal economy using the MIMIC, the adjustment procedure could be calibrated considering the INEI's first study about the informal economy in Peru. Another criticism of the MIMIC model is the fact that illicit activities cannot be completely separated from informal activities because the former groups hide their income. Finally, the model requires a great amount of data and, therefore, it is not possible to analyze only one country.

Some conclusions can be obtained after all the research review. First of all, the need to reinforce theoretical framework in order to understand the informal economy as agents' behavior. Secondly, a unique solution (a recipe) is not feasible: we need to adapt the possible solutions to the specific causes of informal economy in each country. Thirdly, all agents (government and institutions, formal sector, informal sector and individual agents) must be considered because each particular behavior exerts an effect on the dimension of the informal economy. Fourthly, facts such as confidence in the government and politicians, transparency and efficiency in the government's expenditures, elimination of corruption, increasing the perceived social welfare and education are probably more important and effective variables to take into account to reduce informality than tax reduction programs. A complete set of formalization policies must be considered besides creating and maintaining economic growth. Lastly, it should be understood that the final result will be seen in the long run.

From the point of view of public management, trying to solve the problem does not only mean taking the perspective of the rational economic actor but combining it with that of the social actor: whether an agent's participation in the informal sector is due to a low moral tax measured or by what is called the civil morality (Williams, Horodnic, \& Burkinshaw, 2016). In this context, the way to solve the informality problem would be to incentivize the tax morality, independently of the other policy measures that the state can adopt. But for this to happen, governments must increase, promote and communicate (not only with rules but with their actions) the "state morality» as an institution (Williams, Horodnic, \& Burkinshaw, 2016, p. 368). This state morality has to do with the moral responsibilities of the state. For the application of this idea, the thought of Williams (1923) must be followed while defining a conception of the state:

A community of people socially united; secondly, a piece of political machinery termed a government, and administered by a corps of officials termed a magistracy; and thirdly, a body of rules or maxims, written or unwritten, determining the scope of this public authority and the manner of its exercise. (p. 22).

And one way to increase both the civic morality (which includes tax morality) and the state morality is through education.

It is also necessary to understand that informal agents are not criminals and that informality should be analyzed considering two basic things that sometimes go unnoticed: on the one hand, informality in Peru has a lot to do with social and economic inequalities; and on the other hand, it is a mechanism of capitalist development of an enterprise that, if 
well managed, could positively stimulate economic growth. From this standpoint of view, government's policies must-see at informals as entrepreneurs who requiered in most cases education, social protection, financing, technology and improvement of skills to develop their enterprises (Lupi, 2018). And that's the place where management science could help the informal entities to successfully achieve their potential. 
Appendix A1

MIMIC estimation the size of the informal economy in Peru, Latin America and OCDE

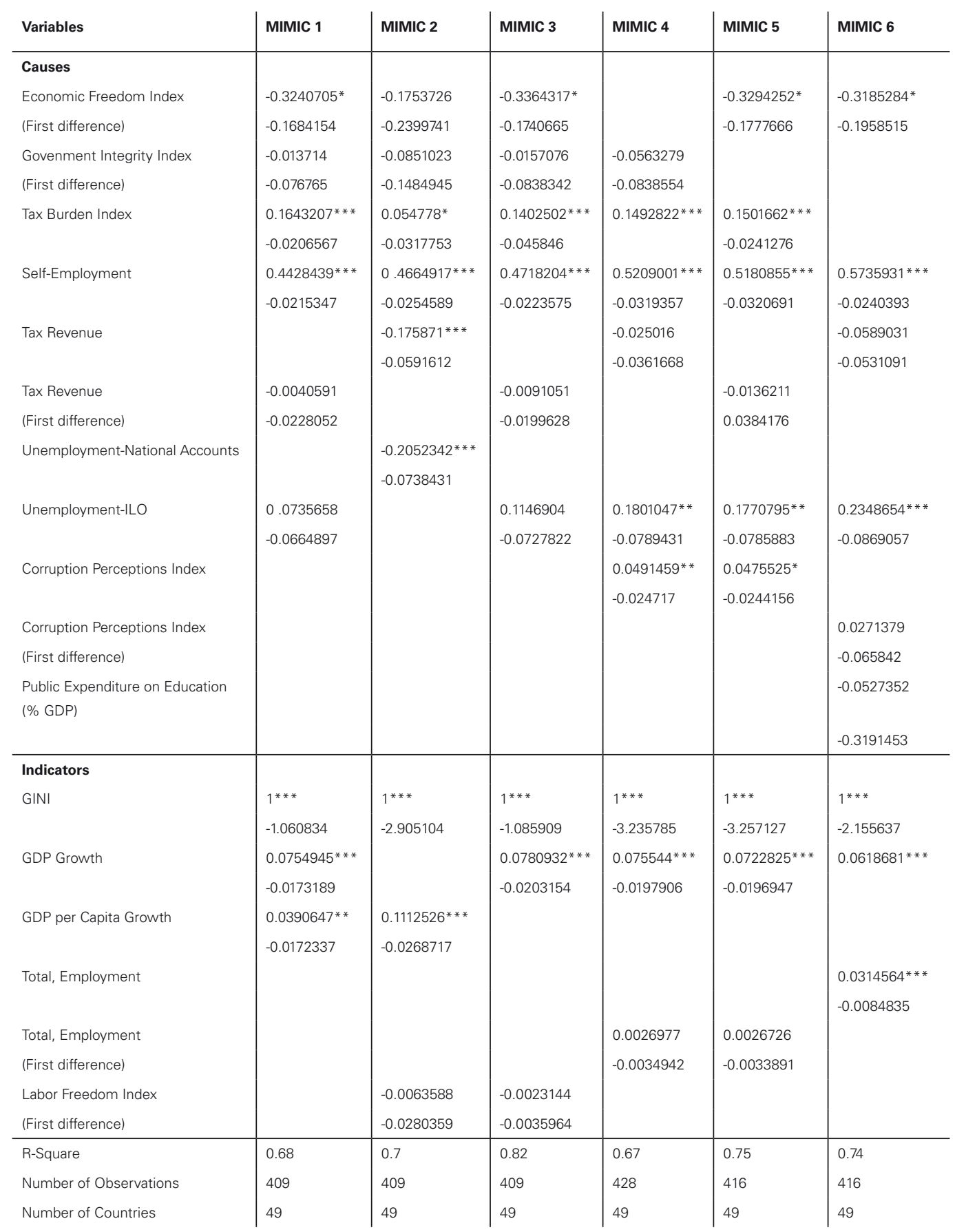

${ }^{* * *} \mathrm{p}<0.01,{ }^{* *} \mathrm{p}<0.05,{ }^{*} \mathrm{p}<0.1$ 
Appendix A2

GMM 2SLS estimation for the informal economy impact on the economic growth and tax collection

\begin{tabular}{|c|c|c|c|}
\hline & $\begin{array}{l}\text { Latin America and OECD } \\
\text { GMM } 3 \text { SLS }\end{array}$ & $\begin{array}{l}\text { Latin America } \\
\text { GMM 3SLS }\end{array}$ & $\begin{array}{l}\text { OECD } \\
\text { GMM 3SLS }\end{array}$ \\
\hline Variables equation 1 & PBI Per Capita & PBI Per Capita & PBI Per Capita \\
\hline$B(0)$ & $\begin{array}{l}16.04457^{* * *} \\
-0.5732274\end{array}$ & $\begin{array}{l}6.990063 * * * \\
-0.9415331\end{array}$ & $\begin{array}{l}5.814696 * * * \\
-0.7946755\end{array}$ \\
\hline Size of the Informal Economy & $1.477571^{* * *}$ & $0.0559854^{*}$ & -0.062357 \\
\hline (First difference) & -0.3622342 & -0.0329249 & -0.0666144 \\
\hline Self-Employment & $-0.5454918 * * *$ & $-1.392917 * * *$ & $-0.5218654 * * *$ \\
\hline (First difference) & -0.2129625 & -0.2087917 & -0.02568 \\
\hline Government Expenditure on Education (\% GDP) & $0.4261664^{* *}$ & & \\
\hline (First difference) & -0.1867628 & & \\
\hline \multirow[t]{2}{*}{ Business Freedom Index } & & $0.0140836 * * *$ & $0.026601 * * *$ \\
\hline & & -0.003448 & -0.0045991 \\
\hline Tax Revenue & & $2.027748^{* * *}$ & $0.2568484 * *$ \\
\hline (logaritthm) & & -0.5520688 & -0.0586602 \\
\hline Labor force & & $2.5125^{* *}$ & $2.25565 * * *$ \\
\hline (First difference) & & -1.12356 & -8.135659 \\
\hline \multirow[t]{2}{*}{ Monetary Freedom Index } & & 0.0070551 & $0.0358568 * * *$ \\
\hline & & -0.0061657 & -0.0081335 \\
\hline Corruption Perceptions Index & $-0.0214082^{*}$ & -0.0047226 & -0.0217506 \\
\hline (First difference) & -0.0118914 & -0.0084066 & -0.0208546 \\
\hline Variables equation 2 & Tax Revenue & Tax Revenue & Tax Revenue \\
\hline \multirow[t]{2}{*}{$C(0)$} & $5.50209 * * *$ & 1.011502 & -2.525607 \\
\hline & -0.8938271 & -1.052863 & -2.675952 \\
\hline Size of the Informal Economy & $-0.6182572 * * *$ & -0.0128533 & $-1.088846^{* * *}$ \\
\hline (First difference) & -0.2276938 & -0.0214206 & -0.4123225 \\
\hline Govenment Integrity Index & 0.0154201 & & \\
\hline (First difference) & -0.0291806 & & \\
\hline \multirow[t]{2}{*}{ Agriculture Value Added (\% GDP) } & 0.0120444 & & \\
\hline & -0.0265245 & & \\
\hline \multirow[t]{2}{*}{ Monetary Freedom Index } & -0.0086932 & & \\
\hline & -0.0119547 & & \\
\hline \multirow[t]{2}{*}{ Unemployment-National Accounts } & $-0.0137676^{*}$ & $-0.0585898 * *$ & -0.0107234 \\
\hline & -0.011063 & -0.0239664 & -0.044985 \\
\hline Tax Burden Index & & 0.005594 & $0.2955619 * *$ \\
\hline (First difference) & & -0.021425 & -0.123385 \\
\hline GDP Per Capita & & $0.1079121 * *$ & $0.515518^{* *}$ \\
\hline (First difference) & & -0.0487468 & -0.2301558 \\
\hline \multirow[t]{2}{*}{ Investment Freedom Index } & & 0.1580409 & \\
\hline & & -0.1891178 & \\
\hline Government Expenditure on Education (\% GDP) & & $0.2335999 * *$ & $1.620124 * *$ \\
\hline (First difference) & & -0.09444 & -0.775857 \\
\hline Number of Observations & 225 & 60 & 177 \\
\hline Hansen Test (P-value) & 0.061 & 0.075 & 0.057 \\
\hline
\end{tabular}

Robust standar error in parentheses

${ }^{* * *} p<0.01,{ }^{* *} p<0.05, * p<0.1$ 


\section{Appendix B}

Size of the informal economy as a \% of the GDP: Latin America countries

\begin{tabular}{|c|c|c|c|c|c|c|c|c|c|c|c|c|c|c|c|}
\hline ฮ్ & $\begin{array}{l}\text { đ̋ } \\
\stackrel{\sim}{0}\end{array}$ & 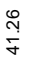 & 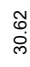 & $\begin{array}{l}\hat{\oplus} \\
\dot{\rho}\end{array}$ & 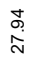 & 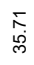 & 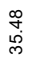 & 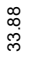 & 志 & 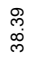 & $\begin{array}{l}\text { ?े } \\
\text { 心 }\end{array}$ & 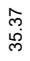 & $\begin{array}{l}\text { స్ } \\
\text { న్లి }\end{array}$ & $\begin{array}{l}\infty \\
\infty \\
\hat{m}\end{array}$ & $\begin{array}{l}\mathscr{Q} \\
\text { స }\end{array}$ \\
\hline & $\begin{array}{l}\text { \& } \\
\text { ํ. }\end{array}$ & $\begin{array}{l}\bar{\infty} \\
\dot{j}\end{array}$ & $\begin{array}{l}\text { Oे } \\
\text { id }\end{array}$ & $\underset{\infty}{\infty}$ & 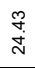 & 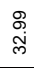 & 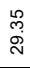 & ल) & $\frac{\stackrel{\leftrightarrow}{m}}{\dot{m}}$ & $\begin{array}{l}\stackrel{\llcorner}{\infty} \\
\stackrel{m}{m}\end{array}$ & 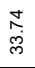 & $\stackrel{\substack{\sim \\
\sim}}{\sim}$ & 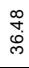 & $\begin{array}{l}\text { ले } \\
\text { लm}\end{array}$ & $\begin{array}{l}\hat{+} \\
\dot{J}\end{array}$ \\
\hline & $\underset{\dot{c}}{\bar{c}}$ & 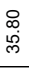 & $\begin{array}{l}\stackrel{0}{\stackrel{\leftrightarrow}{N}} \\
\stackrel{N}{N}\end{array}$ & 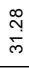 & $\underset{\stackrel{N}{*}}{\stackrel{+}{N}}$ & 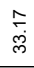 & $\begin{array}{l}\text { : } \\
\text { Nై }\end{array}$ & $\frac{\hat{\varphi}}{\dot{m}}$ & $\begin{array}{l}\text { Fै. } \\
\text { N }\end{array}$ & $\begin{array}{l}\text { o } \\
\infty \\
\text { లె }\end{array}$ & $\begin{array}{l}\text { ్ֶ } \\
\text { में }\end{array}$ & $\begin{array}{l}\text { ర్లై } \\
\text { }\end{array}$ & 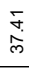 & 今̃ & 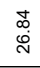 \\
\hline$\stackrel{+}{\stackrel{N}{N}}$ & 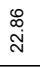 & 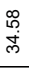 & $\frac{\mathcal{N}}{\dot{m}}$ & $\begin{array}{l}\bar{m} \\
\text { fं }\end{array}$ & 芯 & 总 & $\begin{array}{l}\text { L్ } \\
\text { लై }\end{array}$ & $\begin{array}{l}\text { N̦ } \\
\text { Oे }\end{array}$ & $\begin{array}{l}\text { స్م } \\
\text { న్ }\end{array}$ & 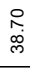 & $\stackrel{\llcorner}{\stackrel{\infty}{\infty}}$ & 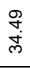 & $\begin{array}{l}\mathscr{8} \\
\stackrel{्}{0}\end{array}$ & 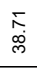 & $\stackrel{\stackrel{\infty}{N}}{\stackrel{N}{N}}$ \\
\hline$\frac{m}{c}$ & $\underset{\sim ָ}{\sim ్ N}$ & 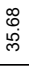 & $\stackrel{\infty}{\stackrel{\infty}{\infty}}$ & $\begin{array}{c}\stackrel{\infty}{\infty} \\
\stackrel{m}{m}\end{array}$ & 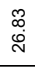 & $\begin{array}{l}: \\
\stackrel{0}{0}\end{array}$ & $\begin{array}{l}\text { ণ্ } \\
\text { j్ }\end{array}$ & 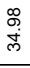 & $\begin{array}{l}\text { ले } \\
\text { నे }\end{array}$ & 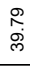 & $\begin{array}{l}\stackrel{\infty}{0} \\
\infty \\
\infty\end{array}$ & $\begin{array}{l}\text { F̃ } \\
\text { ¿े. }\end{array}$ & 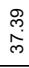 & $\begin{array}{c}\text { m. } \\
\stackrel{\infty}{\infty}\end{array}$ & $\begin{array}{l}\stackrel{0}{ } \\
\stackrel{\infty}{N}\end{array}$ \\
\hline 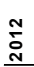 & $\underset{\sim}{\stackrel{\infty}{\sim}}$ & $\begin{array}{l}\text { शे } \\
\text { J }\end{array}$ & 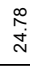 & $\begin{array}{c}\infty \\
\infty \\
\infty \\
\infty \\
m\end{array}$ & $\begin{array}{l}\frac{0}{\mathscr{N}} \\
\stackrel{\sim}{\circ}\end{array}$ & $\begin{array}{l}\stackrel{\text { o }}{\infty} \\
\text { p. }\end{array}$ & 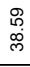 & 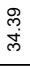 & $\begin{array}{l}\infty \\
\infty \\
\infty \\
\text { లె }\end{array}$ & $\begin{array}{l}\text { Ñ } \\
\text { Oे }\end{array}$ & $\begin{array}{l}0 \\
\text { ơ } \\
\text { p. }\end{array}$ & 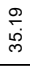 & 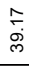 & $\begin{array}{l}\bar{\infty} \\
\hat{m}\end{array}$ & $\begin{array}{l}\hat{o} \\
\stackrel{N}{N}\end{array}$ \\
\hline 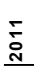 & 离 & $\begin{array}{l}\overline{\text { j}} \\
\stackrel{\text { V}}{ }\end{array}$ & $\stackrel{\llcorner}{\stackrel{\circ}{\circ}}$ & 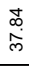 & 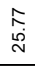 & 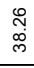 & $\frac{\Omega}{\dot{0}}$ & $\begin{array}{l}\widehat{0} \\
\dot{j}\end{array}$ & م્ల్లె & $\begin{array}{l}\bar{g} \\
\text { O্ }\end{array}$ & $\begin{array}{l}\bar{\infty} \\
\infty \\
\infty \\
\infty\end{array}$ & @્ & $\underset{\infty}{\stackrel{\varphi}{\infty}}$ & $\begin{array}{l}8 \\
\infty \\
\infty \\
m\end{array}$ & $\begin{array}{l}0 \\
\stackrel{\infty}{0} \\
\infty \\
\sim\end{array}$ \\
\hline i̊ & 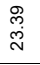 & $\stackrel{\hat{p}}{\stackrel{N}{g}}$ & $\begin{array}{l}\hat{N} \\
\stackrel{\text { d }}{\text { N }}\end{array}$ & $\begin{array}{c}\stackrel{\infty}{\infty} \\
\stackrel{m}{m}\end{array}$ & 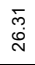 & 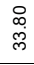 & 雨 & $\begin{array}{l}\text { 莳 } \\
\text { में }\end{array}$ & $\begin{array}{l}\stackrel{8}{\infty} \\
\stackrel{\infty}{N}\end{array}$ & $\begin{array}{l}\text { Fै } \\
\text { O্ }\end{array}$ & స్ & $\begin{array}{l}\infty \\
\infty \\
\dot{m}\end{array}$ & $\underset{\substack{\infty \\
\text { N }}}{N}$ & 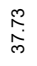 & $\begin{array}{l}\stackrel{\infty}{N} \\
\stackrel{\sim}{N}\end{array}$ \\
\hline : & $\begin{array}{l}\stackrel{8}{0} \\
\dot{N}\end{array}$ & $\frac{\dddot{m}}{\frac{\pi}{\sigma}}$ & $\begin{array}{l}\hat{\omega} \\
\stackrel{\leftrightarrow}{N}\end{array}$ & $\begin{array}{l}\bar{\infty} \\
\infty \\
\infty\end{array}$ & 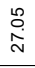 & 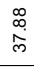 & 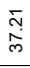 & $\underset{\substack{\hat{\infty} \\
\text { jo }}}{ }$ & సָ̀ & $\begin{array}{l}\stackrel{\leftrightarrow}{\oplus} \\
\stackrel{m}{m}\end{array}$ & 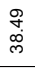 & $\begin{array}{l}\text { ठ্. } \\
\text { p. }\end{array}$ & $\begin{array}{l}\text { त् } \\
\text { g্ }\end{array}$ & $\begin{array}{l}\stackrel{8}{0} \\
\infty \\
\infty\end{array}$ & $\begin{array}{l}\stackrel{\leftrightarrow}{0} \\
\stackrel{N}{0}\end{array}$ \\
\hline $\begin{array}{l}\infty \\
\stackrel{\text { ڤे }}{N}\end{array}$ & $\begin{array}{l}\stackrel{\infty}{. j} \\
\stackrel{\sim}{\sim}\end{array}$ & $\begin{array}{l}\text { o } \\
\text { j }\end{array}$ & $\begin{array}{l}\stackrel{0}{0} \\
\stackrel{\text { N }}{ }\end{array}$ & $\begin{array}{l}\text { Dొ } \\
\text { ర్ } \\
\text { లె }\end{array}$ & 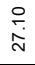 & $\begin{array}{l}\hat{a} \\
\text { di }\end{array}$ & 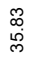 & ల్ల్లా & $\underset{\dot{m}}{\stackrel{N}{m}}$ & $\begin{array}{l}\infty \\
\circ \\
\infty \\
\infty\end{array}$ & $\begin{array}{l}\stackrel{0}{0} \\
\text { ì }\end{array}$ & $\frac{0}{\dot{0}}$ & $\begin{array}{l}\hat{\infty} \\
\infty \\
\infty \\
\infty\end{array}$ & $\begin{array}{l}\hat{N} \\
\infty \\
\infty\end{array}$ & $\begin{array}{l}\text { வ } \\
\infty \\
\text { ஸे }\end{array}$ \\
\hline ڤे & $\underset{\sim ָ}{\sim}$ & $\begin{array}{l}\bar{y} \\
\text { go }\end{array}$ & 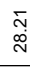 & $\begin{array}{l}\bar{\sigma} \\
\dot{f}\end{array}$ & 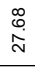 & $\begin{array}{l}\text { त्र } \\
\text { ర్ల }\end{array}$ & $\begin{array}{l}\hat{y} \\
0 \\
\text { ల }\end{array}$ & ল্ল & 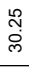 & 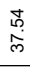 & $\begin{array}{l}\text { ¿ } \\
0 \\
\dot{ల}\end{array}$ & 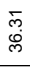 & $\begin{array}{l}\hat{\infty} \\
\text { of }\end{array}$ & $\begin{array}{l}\infty \\
\infty \\
\infty \\
\infty\end{array}$ & $\begin{array}{l}\infty \\
\stackrel{\infty}{\infty} \\
\stackrel{\infty}{N}\end{array}$ \\
\hline $\begin{array}{l}\text { ¿ें } \\
\text { ㄱ. }\end{array}$ & $\underset{\stackrel{\sim}{\sim}}{\bar{j}}$ & $\begin{array}{l}8 \\
\dot{6} \\
\dot{\sigma}\end{array}$ & $\begin{array}{l}\tilde{N} \\
\text { வे }\end{array}$ & 勍 & $\stackrel{\infty}{\infty}$ & $\stackrel{\text { no }}{\stackrel{\text { m}}{m}}$ & $\begin{array}{l}\overline{1} \\
\stackrel{\infty}{0}\end{array}$ & 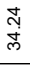 & $\begin{array}{l}\widehat{\hat{\sigma}} \\
\dot{\tilde{j}}\end{array}$ & $\begin{array}{l}\stackrel{8}{0} \\
\stackrel{m}{m}\end{array}$ & $\begin{array}{l}\text { ల్ల్ల } \\
\dot{ల}\end{array}$ & 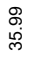 & $\begin{array}{l}\hat{\circ} \\
\text { ه্లি }\end{array}$ & $\begin{array}{l}\stackrel{\infty}{\dddot{q}} \\
\stackrel{q}{0}\end{array}$ & $\begin{array}{l}0 \\
\text { ల్ల } \\
\text { లं }\end{array}$ \\
\hline ڤ̊ํํ & $\begin{array}{l}\ddot{\leftrightarrow} \\
\stackrel{\sim}{\circ}\end{array}$ & \begin{tabular}{l}
$\stackrel{\infty}{N}$ \\
\multirow{f}{*}{}
\end{tabular} & 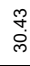 & 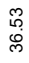 & $\begin{array}{l}\stackrel{8}{\infty} \\
\stackrel{\infty}{N}\end{array}$ & 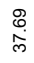 & 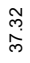 & 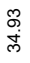 & $\begin{array}{l}\text { to } \\
\text { d. }\end{array}$ & 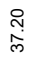 & 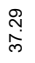 & $\begin{array}{l}\text { 守 } \\
\text { 邑 }\end{array}$ & 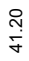 & $\begin{array}{l}\stackrel{\text { I }}{\mathrm{V}} \\
\text { }\end{array}$ & $\begin{array}{l}\text { J } \\
\text { d. }\end{array}$ \\
\hline ¿্ं & $\begin{array}{l}\stackrel{\infty}{\sim} \\
\stackrel{\sim}{\sim}\end{array}$ & 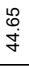 & 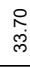 & $\begin{array}{l}\stackrel{\tilde{m}}{\text { m }} \\
\text { }\end{array}$ & $\begin{array}{l}\stackrel{N}{N} \\
\stackrel{N}{N}\end{array}$ & 㖷 & 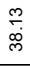 & స్లె & $\begin{array}{l}\text { ष্. } \\
\text { बें }\end{array}$ & $\begin{array}{l}\stackrel{8}{0} \\
\dot{+}\end{array}$ & $\begin{array}{l}\stackrel{\rho}{1} \\
\infty \\
\infty\end{array}$ & $\begin{array}{l}\sim \\
\infty \\
\infty \\
\infty \\
\end{array}$ & 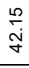 & 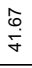 & $\begin{array}{l}\text { ల్లా } \\
\text { ळे }\end{array}$ \\
\hline$\stackrel{\text { : }}{\stackrel{N}{N}}$ & $\begin{array}{l}\text { ₹ } \\
\stackrel{\infty}{\sim}\end{array}$ & $\stackrel{\infty}{\stackrel{\infty}{f}}$ & $\begin{array}{l}\stackrel{0}{0} \\
\text { p }\end{array}$ & $\begin{array}{l}\hat{\sigma} \\
\text { d्ల }\end{array}$ & \begin{tabular}{l}
\multirow{N}{N}{} \\
N
\end{tabular} & 苫 & $\begin{array}{l}\text { ల్ } \\
\text { હ্ల) }\end{array}$ & $\begin{array}{l}\text { స్ } \\
\text { ָे }\end{array}$ & $\begin{array}{l}\text { N̦ } \\
\text { హ్ల }\end{array}$ & 足 & 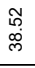 & $\underset{\substack{j \\
\text { in }}}{\bar{n}}$ & $\stackrel{\stackrel{\infty}{f}}{\dot{\sigma}}$ & 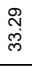 & $\stackrel{\text { No }}{\stackrel{0}{\circ}}$ \\
\hline ڤั & $\begin{array}{l}\infty \\
\stackrel{\infty}{\infty} \\
\stackrel{\infty}{0}\end{array}$ & 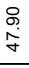 & 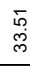 & 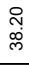 & $\begin{array}{c}\text { مٌ } \\
\stackrel{N}{N}\end{array}$ & 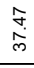 & 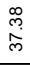 & $\stackrel{m}{\dot{p}}$ & $\begin{array}{l}\stackrel{\leftrightarrow}{\leftrightarrow} \\
\text { ָे }\end{array}$ & 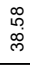 & $\begin{array}{l}\stackrel{8}{0} \\
\text { im }\end{array}$ & $\begin{array}{l}\stackrel{R}{0} \\
\dot{0}\end{array}$ & $\begin{array}{l}\stackrel{\text { İ }}{\text { f }}\end{array}$ & 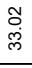 & $\begin{array}{l}\text { ஜू } \\
\text { } \\
\end{array}$ \\
\hline$\stackrel{i}{\stackrel{i}{*}}$ & $\begin{array}{l}\stackrel{L}{0} \\
\stackrel{\sim}{N}\end{array}$ & $\begin{array}{c}\bar{\sigma} \\
\dot{\rho}\end{array}$ & $\underset{N}{\stackrel{N}{N}}$ & $\stackrel{\infty}{\stackrel{\infty}{\tilde{m}}}$ & \begin{tabular}{l}
\multirow{+}{*}{} \\
$\stackrel{N}{N}$
\end{tabular} & $\begin{array}{l}\stackrel{0}{0} \\
\dot{m}\end{array}$ & $\begin{array}{l}\text { m } \\
\stackrel{+}{+}\end{array}$ & 周 & बे. & $\begin{array}{l}\bar{\infty} \\
\stackrel{m}{m}\end{array}$ & $\begin{array}{l}\text { \& } \\
\dot{0} \\
\text {. }\end{array}$ & 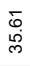 & $\underset{\sim}{\stackrel{\sim}{\sim}}$ & $\begin{array}{l}\stackrel{\infty}{\infty} \\
\stackrel{m}{m}\end{array}$ & $\frac{0}{\stackrel{\sigma}{N}}$ \\
\hline : & 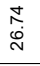 & 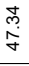 & 울 & $\underset{\text { ì }}{\stackrel{+}{m}}$ & $\stackrel{\infty}{\infty} \underset{\sim}{\infty}$ & 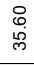 & $\begin{array}{l}\stackrel{2}{2} \\
\text { ím }\end{array}$ & $\stackrel{\text { L }}{\frac{m}{m}}$ & 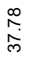 & 离 & $\begin{array}{l}\text { Fै } \\
\text { மू }\end{array}$ & $\begin{array}{l}\text { o } \\
\text { वे } \\
\text { di }\end{array}$ & $\stackrel{i}{i}$ & $\begin{array}{l}\stackrel{\circ}{\rho} \\
\stackrel{m}{m}\end{array}$ & $\begin{array}{l}\infty \\
\infty \\
\infty \\
\infty\end{array}$ \\
\hline$\stackrel{\text { ๖े }}{\circ}$ & $\stackrel{\frac{n}{\sim}}{\stackrel{N}{N}}$ & $\begin{array}{l}\infty \\
\substack{\infty \\
\infty \\
\infty}\end{array}$ & $\frac{\varphi}{\dot{m}}$ & 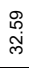 & $\begin{array}{l}\infty \\
\stackrel{\infty}{N} \\
\text { D. }\end{array}$ & $\begin{array}{l}\stackrel{\circ}{\infty} \\
\stackrel{\infty}{m}\end{array}$ & 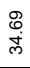 & 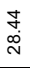 & $\begin{array}{l}\text { مी } \\
\text { मे }\end{array}$ & $\begin{array}{l}\text { ? } \\
\text { एెల }\end{array}$ & $\begin{array}{l}\stackrel{\leftrightarrow}{0} \\
\text { }\end{array}$ & $\begin{array}{l}\bar{m} \\
\text { d্ల }\end{array}$ & $\begin{array}{l}\hat{0} \\
\dot{q}\end{array}$ & $\begin{array}{l}\text { ¿े } \\
\text { d. }\end{array}$ & \begin{tabular}{l}
\multirow{0}{0}{} \\
$\stackrel{\infty}{N}$
\end{tabular} \\
\hline $\begin{array}{l}\infty \\
\stackrel{\circ}{\sigma}\end{array}$ & 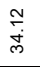 & 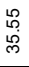 & 号 & 尽 & $\begin{array}{l}\hat{\infty} \\
\stackrel{N}{N}\end{array}$ & $\frac{\mathcal{F}}{\dot{m}}$ & 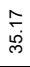 & 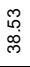 & $\begin{array}{l}\text { mे } \\
\text { से }\end{array}$ & 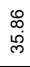 & $\begin{array}{l}\dot{+} \\
\text { Jे }\end{array}$ & $\begin{array}{l}\text { Jे } \\
\text { d) }\end{array}$ & 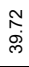 & $\underset{m}{\check{m}}$ & $\begin{array}{l}0 \\
0 \\
\infty \\
\text { ஸे }\end{array}$ \\
\hline à & 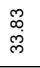 & $\begin{array}{l}\stackrel{0}{2} \\
\stackrel{0}{+}\end{array}$ & $\begin{array}{l}i \\
\dot{\phi}\end{array}$ & $\begin{array}{c}\text { ळ } \\
\text { స్లె }\end{array}$ & $\begin{array}{l}\hat{N} \\
\stackrel{\infty}{N}\end{array}$ & $\begin{array}{l}\mathscr{\varrho} \\
\dot{m} \\
\dot{m}\end{array}$ & 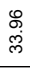 & $\underset{\substack{\infty \\
\text { ల్ల }}}{ }$ & $\begin{array}{l}\hat{O} \\
\text { Dे }\end{array}$ & 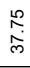 & $\begin{array}{l}\text { లి } \\
\text { iे }\end{array}$ & 帘 & 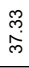 & $\begin{array}{l}\text { t. } \\
\text { d }\end{array}$ & $\begin{array}{l}\infty \\
\infty \\
\stackrel{\omega}{N}\end{array}$ \\
\hline ஃ & $\begin{array}{l}0 \\
\stackrel{0}{0} \\
\text { D. }\end{array}$ & $\begin{array}{l}\infty \\
\infty \\
\dot{m}\end{array}$ & $\frac{0}{\dot{m}}$ & $\begin{array}{l}\infty \\
\infty \\
0 \\
0 \\
0\end{array}$ & $\begin{array}{l}\infty \\
\infty \\
\dot{m}\end{array}$ & 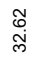 & $\begin{array}{l}\hat{\text { oे }} \\
\text { oे }\end{array}$ & $\begin{array}{l}\text { oे } \\
\dot{j}\end{array}$ & 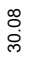 & 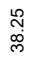 & $\stackrel{\text { m}}{\bar{m}}$ & $\begin{array}{l}\hat{a} \\
\stackrel{\infty}{\infty}\end{array}$ & $\begin{array}{l}\infty \\
\text { ల్ల }\end{array}$ & $\begin{array}{l}\text { m } \\
\stackrel{్}{0}\end{array}$ & $\begin{array}{l}\stackrel{\circ}{\stackrel{N}{N}} \\
\stackrel{2}{n}\end{array}$ \\
\hline 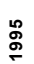 & 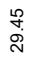 & 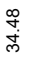 & 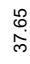 & $\underset{N}{\Gamma}$ & $\underset{m}{\stackrel{N}{m}}$ & $\begin{array}{l}\stackrel{\circ}{\circ} \\
\stackrel{్}{~}\end{array}$ & $\stackrel{\infty}{\stackrel{\infty}{ల ్ ల ె ~}}$ & 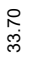 & $\underset{\text { స్ల }}{\bar{j}}$ & $\begin{array}{l}\bar{\sigma} \\
\infty \\
\infty\end{array}$ & $\begin{array}{l}\text { \% } \\
\text { bू }\end{array}$ & $\begin{array}{l}\text { N్ } \\
\text { d্ల }\end{array}$ & $\stackrel{\sim}{\stackrel{్}{j}}$ & $\underset{\substack{\mathcal{N} \\
\text { fo }}}{\mathcal{N}}$ & $\begin{array}{l}\text { of } \\
\stackrel{\infty}{\infty}\end{array}$ \\
\hline 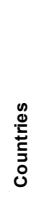 & 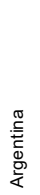 & 离 & 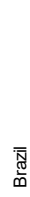 & $\begin{array}{l}\frac{\pi}{0} \\
\frac{0}{\varepsilon} \\
\frac{0}{0}\end{array}$ & 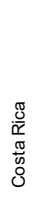 & 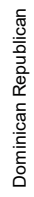 & 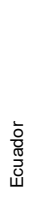 & 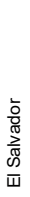 & 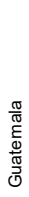 & 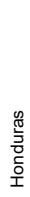 & $\begin{array}{l}\text { 蛹 } \\
\frac{\pi}{\pi} \\
\frac{0}{z}\end{array}$ & 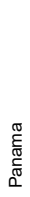 & 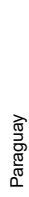 & 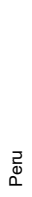 & 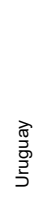 \\
\hline
\end{tabular}




\begin{tabular}{|c|c|}
\hline 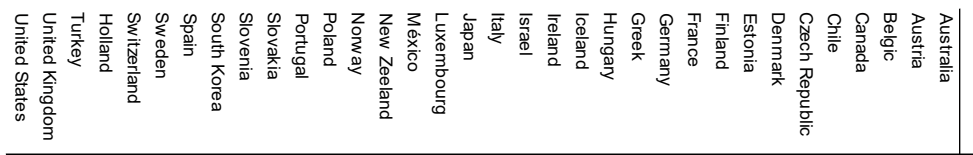 & \\
\hline & \\
\hline$\infty \sim G \infty C^{\infty}$ & \\
\hline 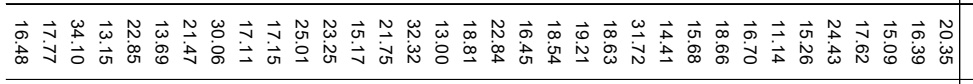 & 常 \\
\hline 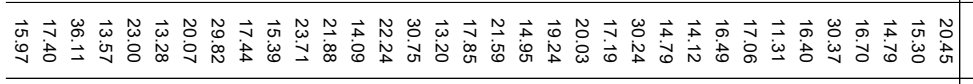 & : \\
\hline 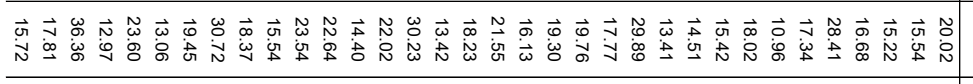 & : \\
\hline 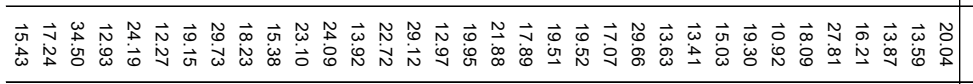 & 5 \\
\hline 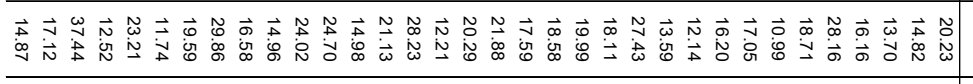 & 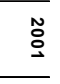 \\
\hline 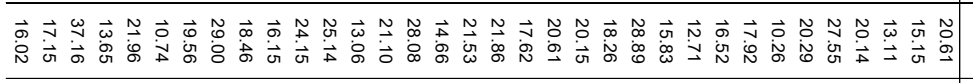 & c \\
\hline 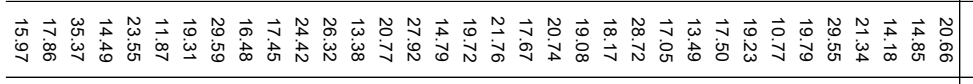 & 䲩 \\
\hline 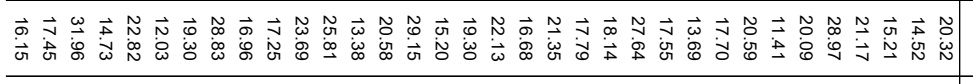 & : \\
\hline 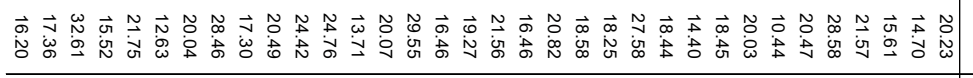 & 該 \\
\hline 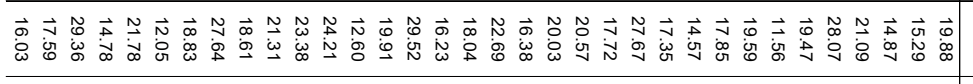 & : \\
\hline 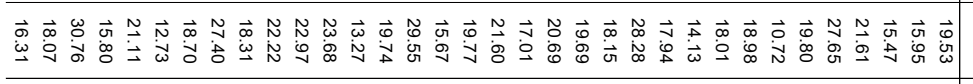 & E \\
\hline 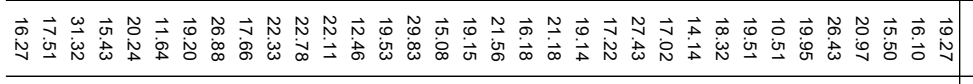 & 呅 \\
\hline 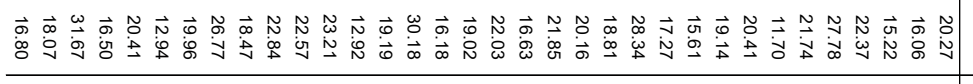 & : \\
\hline 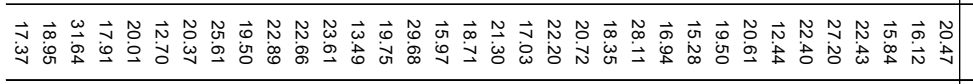 & 䓴 \\
\hline 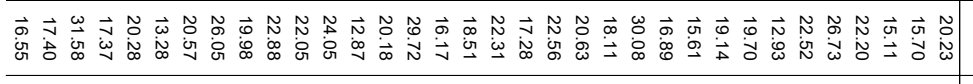 & $\overbrace{\stackrel{\Omega}{ٍ}}$ \\
\hline 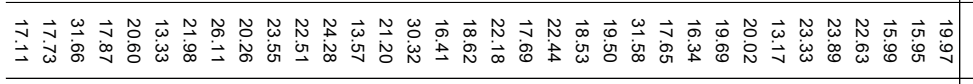 & 产 \\
\hline 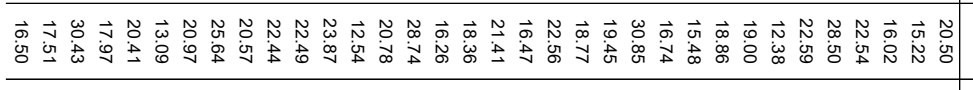 & $\stackrel{\breve{\omega}}{\vec{\omega}}$ \\
\hline 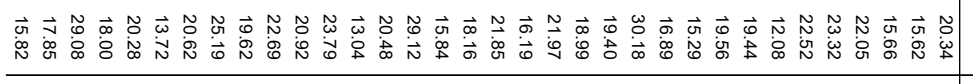 & 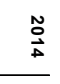 \\
\hline 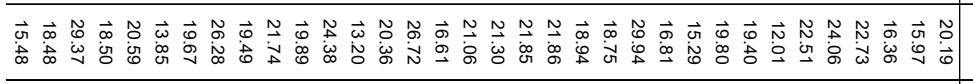 & $\begin{array}{c}\tilde{0} \\
\vec{\omega}\end{array}$ \\
\hline 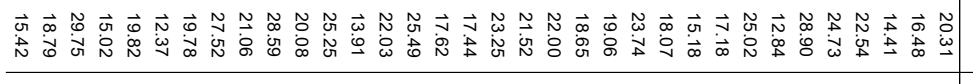 & مَ \\
\hline & \\
\hline
\end{tabular}


Appendix D

GMM and GMM 3SLS estimation of the informal economy impact

on the economic growth and the tax collection

\begin{tabular}{l|l|l} 
GMM & $\begin{array}{l}\text { Latin America and OECD } \\
\text { (tax revenue) }\end{array}$ & $\begin{array}{l}\text { Latin America and OECD } \\
\text { (PBI per capita) }\end{array}$ \\
\hline Size of the Informal Economy & $-0.266^{*}$ & $-0.1564^{* * *}$ \\
GMM 3SLS & Latin America (PBI per capita) & OECD (PBI per capita) \\
\hline Size of the Informal Economy & $0.0559^{*}$ & -0.062 \\
Self-Employment & $-1.392917^{* * *}$ & $-0.5218654^{* * *}$ \\
Business Freedom Index & $0.0140836^{* * *}$ & $0.026601^{* * *}$ \\
Tax Revenue & $2.027748^{* * *}$ & $0.2568484^{* * *}$ \\
Labor force & $2.5125^{* *}$ & $2.25565^{* * *}$ \\
GMM 3SLS & Latin America (tax revenue) & OECD (tax revenue) \\
\hline Size of the Informal Economy & -0.0128533 & $-1.088846^{* * *}$ \\
Unemployment-National Accounts & $-0.0585898^{* *}$ & -0.0107234 \\
Tax Burden Index & 0.005594 & $0.2955619^{* *}$ \\
GDP Per Capita & $0.1079121^{* *}$ & $0.515518^{* *}$
\end{tabular}




\section{bibliografía}

Abid, M.

2016

Size and implication of the informal

economy in African countries: Evidence

from a structural model. International

Economic Journal, 30(4), 571-598. DOI:

10.1080/10168737.2016.1204342

Achua, C., \& Lussier, R.

2014

Entrepreneurial drive and the informal

economy in Cameroon. Journal of

Developmental Entrepreneurship, 19(4).

Retrieved from: https://doi.org/10.1142/

S1084946714500241

\section{Acock, A.}

2013

Structural equation modeling. Discovering

structural equation Modeling Using Stata,

115-152. Washington: STATA Press.

Adame, V., \& Tuesta, D.

2007

El laberinto de la economía informal:

estrategias de medición e impactos. BBVA

Research Working Paper 17/17.

\section{Allingham, M., \& Sandmo, A.}

1972

Income tax evasions: A theoretical

analysis. Journal of Public Economics, 1(3),

323-338.

\section{Andrei, Tudorel, Stefanescu, Daniela \& Oancea, Bogdan}

2010

Quantitative methods for evaluating the informal economy. Theoretical and Applied Economics, 17(7), 15-24.

\section{Aruoba, S.B.}

The Informal sector, government policy and institutions. Society for Economic Dynamics.
BID.

2010

La era de la productividad. Cómo

transformar las economías desde sus cimientos, 1-29. Washington: Fondo de Cultura Económica.

\section{BID.}

Recaudar no basta: Los impuestos como instrumento de desarrollo. Washington:

Fondo de Cultura Económica.

Bird, R., Martinez-Vasquez, J. \& Torgler, B.

Tax effort in developing countries and high income countries: The impact of corruption, Voice Accountability. Economic Analysis and Policy, 38(1), 55-71.

Bird, R., Martinez-Vasquez, J. \& Torgler, $\mathrm{B}$.

Societal institutions and tax effort. Annals of Economics and Finance, 15(1), 301-351.

\section{Bologna, J.}

The effect of informal employment and corruption on income levels in Brazil. Journal of Comparative Economics, 44(3), 657-695.

\section{Bovi, M., \& Dell'Anno, R.}

The changing nature of the OECD shadow economy. Journal of Evolutionary Economics. Springer 2019.

\section{Brambila, M.J, \& Cazzavillan, G.}

2010

Modeling the informal economy in Mexico. A structural equation approach. The Journal of Developing Areas, 44(1), 345-365. 


\section{bibliografía}

\section{Breusch, T.}

2005

The Canadian underground economy: An examination of Giles and Tedds. Canadian Tax Journal. 53(2), 367-391.

\section{Breusch, T.}

Estimating the underground economy using MIMIC models. EconWPA, 1-35.

\section{Bruton, G.D., Ireland, R.D. \&}

\section{Ketchen Jr., D.J.}

Toward a research agenda on the informal economy. Academy of Management Perspectives, 26(3), 1-11. DOI: 10.5465/ amp.2012.0079

Buehn, A., Dell'Anno, R. \&

\section{Schneider, F.}

2012 Fiscal illusion and the shadow economy: Two sides of the same coin?. Munich Personal RePEC Archive.

\section{CEPLAN}

2016

Economía informal en Perú: Situación actual y perspectivas. Lima.

\section{Céspedes, R. N.}

2015a Crecer no es Suficiente para Reducir la Informalidad. Lima: BCRP.

\section{Chattopadhyay, S., \& Mondal,}

\section{R.}

Investment and growth in a developing economy with vast informal sector. The Journal of Developing Areas, 50(4), 113132.

\section{Chen, A.M.}

La economía informal: definiciones, teorías y políticas. WIEGO
Choy, J.P., \& Thum, M.

2003

Corruption and the shadow economy.

Dresden discussion paper in economics.

\section{Colin, C.W.}

2006 Explaining the hidden enterprise culture. The hidden enterprise culture: Entrepreneurship in the underground economy, 92-97. Massachusetts: Edward Elgar Pub.

\section{Colin, W.C., \& Nadin, S.}

2011 Theorizing the hidden enterprise culture: the nature of entrepreneurship in the shadow economy. Journal Entrepreneurship and Small Business, 14(3), 334-348.

\section{Darbi, W., \& Knott, P.}

2016 Strategizing practices in an informal economy setting: A case of strategic networking. European Management Journal, 34(1), 400-413.

\section{Davoodi, H., \& Grigorian, D.}

Tax potencial vs. tax effort: A cross-country analysis of Armenia Stubbornly Low Tax collection. IMF Working Paper.

\section{De Soto, $\mathrm{H}$.}

El otro sendero. Lima: Instituto Libertad y Democracia.

\section{Dell'Anno, R., \& Schneider, F.}

2009 A complex approach to estimate the shadow economy: The structural equation modeling. In M. Faggini and T. Lux (Eds). Coping with the complexity of economics, 111-130. Verlag, Italy: Springer. 


\section{bibliografía}

Eilat, Y., \& Zinnes, C.

2000

The evolution of the shadow economy in

transitions countries: Consequences for economic growth and donor assistance.

Harvard Institute for International

Development. CAER II Discussion Paper

83, 11-69. Retrieved from: http://citeseerx.

ist.psu.edu/viewdoc/download;jsessionid

=57CDE74EDE5653D9626C731EA5FEA

OC4?doi=10.1.1.470.2018\&rep=rep1\&ty

pe $=p d f$

\section{Elgin, C.}

2010

Political turnover, taxes and the shadow economy. Department of Economics at Bogazici University, 1-51. Retrieved from: http://www.econ.boun.edu.tr/public_html/ RePEc/pdf/201008.pdf

\section{Elgin, C., \& Garcia, M.}

Public trust, taxes and the informal sector. Journal Review of Social, Economic and Administrative Studies, 26(1), 27-44.

Retrieved from: http://www.acarindex.com/ dosyalar/makale/acarindex-1423873575.pdf

\section{Elgin, C., \& Oztunali, O.}

Shadow economies around the World:

Model based estimates. Department of Economics at Bogazici University Working Papers 2012/05, 1-48. Retrieved from: http://www.econ.boun.edu.tr/public_html/ RePEc/pdf/201205.pdf

\section{Elgin, C., \& Oztunali, 0.}

Institutions, informal economy, and economic development. Emerging Markets Finance \& Trade, 50(4), 145-162.
Elgin, C., \& Schneider, F.

Shadow economies in OECD countries:

DGE vs. MIMIC approaches. Journal

Review of Social, Economic and

Administrative Studies, 30(1), 51-75.

\section{Enste, D., \& Schneider, F.}

Increasing shadow economies all over the World - Fiction or reality? Institute for the Study of Labor Discusion Paper 26, 1-65. Retrieved from: http://ftp.iza.org/dp26.pdf

\section{Enste, D.}

2015

The shadow economy in industrial countries. Institute for the Study of Labor Discusion Paper 2(127), 1-11. Retrieved from: https://wol.iza.org/uploads/ articles/457/pdfs/shadow-economy-inindustrial-countries.pdf? $\mathrm{v}=1$

\section{Farrell, D.}

2004

The Hidden dangers of the informal economy. McKinsey Quarterly. Retrieved from: https://www.mckinsey.com/featuredinsights/employment-and-growth/thehidden-dangers-of-the-informal-economy

\section{Feige, E. L.}

\section{Underground activity and institutional} change: productive, protective and predatory behavior in transition economies. In J.M. Nelson, C. Tilly, and L. Walker (Eds.). Transforming post-comunist political economies, 21-34. Washington, DC: National Academy Press.

\section{Feld, L. P., \& Schneider, F.}

Survey on the shadow economy and undeclared earnings in OECD countries. German Economic Review, 11(2), 109-149. 


\section{bibliografía}

Filippin, A., Fiorio, C.,

\& Viviano, E.

2013

The effect of tax enforcement on tax moral. Bank of Italy, Economic Research and International Relations Area Economic Working Paper 937, 1-29.

\section{Frey, B., \& Schneider F.}

2001

Informal and underground economics.

In N.J. Semelser and P.B. Baltes (Eds.).

International Encyclopedia of the Social and Behavioral Sciences (1st ed.), 74417446 .

\section{Frey, B., \& Weck, H.}

1983 Estimating the Shadow Economy: A naive Approach. Oxford Economic Papers, 35(1), 23-44.

Friedman, E., Johnson, E.,

Kaufmann, D., \&

\section{Zoido-Lobaton, P.}

Dodging the Grabbing Hand: The

Determinants of Unofficial Activities in 69 Countries. Journal of Public Economics, 76(3), 459-493.

\section{Galiani, S., \& Weinschelbaum,} F.

Modeling Informality Formally: Households and Firms. Economic Inquiry, 50(3), 821838.

Gibbs, S.R., Mahone Jr., C.E., \& Crump, M.E.S.
2016

Goel, R.K., \& Nelson, M.A.

Shining a light on the shadows: Identifying robust determinants of the Shadow

Economy. Economic Modelling, 58(1), 351-364.

\section{Gokalp, O., \& Lee, S.H.P.}

2016 Competition and corporate tax evasion: An institution-based view. Journal of World Business, 52(2), 258-269.

\section{Goldberger, A.S.}

Structural equation methods in the social sciences. Econometrica, 40(6), 979-1001.

\section{Gómez, S.J., \& Moran, D.}

Informalidad y tributación en América

Latina: Explorando los nexps para mejorar la equidad. Serie Macroeconomia el Desarrollo 124. Santiago: CEPAL.

\section{Gylys, P.}

2005

Economy, anti-economy, underground economy: Conceptual and terminological problems. Ekonomika, 72. Vilnius University Publishing House.

\section{Hart, K.}

Informal income opportunities and urban employment in Ghana. Journal of Modern African Studies, 11(1).

\section{Haslinger, $F$.}

Reciprocity, loyalty, and the growth of the underground-economy: A theoretical note. European Journal of Political Economy, 1(3), 309-323.

(ed.). Academy of Entrepreneurship

Journal 20(2), 33-58. Weavervile, USA:

Jordan Whitney Enterprises Inc. 


\section{bibliografía}

\section{Hassan, M., \& Schneider, F.}

2016

Size and development of the shadow

economies of 157 countries Worldwide:

Updated and new measures from 1999 to

2013. Journal of Global Economics, 4(3),

$1-14$

\section{Hayashi, F.}

2000

Multiple-equation GMM. En F. Hayashi

(Ed.). Econometrics, 258-320.

\section{Hayashi, F.}

2000

Single-equation GMM. En F. Hayashi (Ed.).

Econometrics, 198-202.

\section{Hernandez A.M.}

2009

Estimating the size of the informal

economy in Peru: A currency demand approach. Revista de Ciencias

Empresariales y Económicas.

\section{INEI}

2014

Produción y empleo informal en el Perú: cuenta satélite de la economía informal 2007-2012. Lima: INEI.

\section{INEI}

2016

Evolución de la pobreza monetaria 20092015. Lima: INEI

\section{INEI}

Producción y empleo informal en el Perú: cuenta satélite de la economía informal 2007-2015. Lima: INEI.

\section{INEI}

http://www.inei.gob.pe/. Retrieved from: https://www.inei.gob.pe/estadisticas/ indice-tematico/education/

Joshi, Anuradha; Prichard, Wilson \& Heady, Christopher

2014

Taxing the informal economy: The current state of knowledge and agendas for future research. The Journal of Development Studies, 50(10), 1325-1347.

\section{Kaufmann, D., Kraay, A. \& Mastruzzi, M.}

2014

Governance matters III: Governance indicators for 1996-2014. World Bank.

\section{La Porta, R., \& Shleifer. A.}

2008

The economic consequences of legal origins. Journal of Economic Literature, 46(2), 285-332.

\section{Loayza, N.}

1997

The economics of the informal sector: $A$ simple model and some empirical evidence from Latin America. Lima: The World Bank.

\section{Loayza, N.}

2007

The causes and consequences of informality in Peru. BCRP.

\section{Loayza, N.}

2016 Informality in the process of development and growth. World Bank Group.

\section{Loayza, N. V., Serven, L., \& Sugawara, $\mathbf{N}$.}

2009

Informality in Latin America and the Caribbean. The World Bank.

\section{Lupi, A.}

2018 Main sectoral approaches of policies designed to tackle the informal economy. Retrieved from: https://europa.eu/ capacity4dev/rnsf-mit/wiki/43-mainsectoral-approaches-policies-designedtackle-informal-economy 


\section{bibliografía}

Machado, R.

2014 La economía informal en el Perú: magnitud y determinantes (1980-2011). Apuntes, 41(74), 197-233. Lima: Fondo Editorial de la Universidad del Pacífico.

Mathias, B., Lux, S., Crook, R., Autry, C., \& Zaretzki, R.

2015 Competing against the unknown: The impact of enabling and constraining institutions on the informal economy. Journal of Business Ethics, 127(2), 241264.

\section{McGahan, A.}

2012 Challenges of the informal economy for the field of management. Academy of Management Perspectives, 26(3), 12-21.

\section{MEF.}

Marco macroeconomico multianual 2017 2019 Revisado. LIMA: MEF

\section{Milner, H., \& Rudra, N.}

2015 Globalization and the political benefits of the informal economy. International Studies Review, 17(4), 664-669.

\section{Mukherjee, D.}

Informal economy in emerging economies:

not a substitute but a complement! International Journal of Business and Economic Development, 4(3).

\section{Nagac, K.}

Tax system and informal economy: a cross-country analysis. Applied Economics, 47(17), 1775-1787.

\section{OCDE}

2002

Measuring the non-observed economy: $A$ handbook. OCDE. Paris: OECD Publishing.

\section{OCDE, CEPAL, CIAT, \& BID}

2016

Estadisticas tributarias en América Latina y

el Caribe 2016. Paris: OECD Publishing.

\section{OCDE, ECLAC, CIAT, \& IDB}

2016

Revenue statistics in Latin America and the Caribbean 2016. Paris: OECD.

Retrieved from: http://www.cepal.org/ es/comunicados/america-latina-caribeingresos-tributarios-aumentan-ligeramentepero-aun-se-mantienen

\section{Ogunc, Fethi, Yilmaz \& Gokhan}

2000 Estimating the underground economy in Turkey. The Central Bank of the Republic of Turkey Research Department.

\section{OIT}

1972

Employment, incomes and equality: A strategy for increasing productive employment in Kenya. Ginebra: OIT.

\section{Pathak, S., \& Xavier-Oliveira, E.}

Technology use and availability in entrepreneurship: informal economy as moderator of institutions in emerging economies. The Journal of Technology Transfer, 41(3), 506-529.

\section{Petrescu, I.}

2016 The Effects of economic sanctions on the informal economy. Management Dynamics in the Knowledge Economy, 4(14), 623648.

\section{North, D. C.}




\section{bibliografía}

\section{Sassen, $\mathbf{S}$.}

1994

The Informal economy: Between new

developments and old regulations. The Yale

Law Journal, 103(8), 2289-2304. Retrieved

from: http://www.jstor.org/stable/797048

\section{Satorra, A., \& Bentler, P.}

1994 errors in covariance structure analysis.

SAGE Publications Inc.

\section{Schneider, F., \& Buehn, A.}

Shadow economies and corruption all over the World: Revised estimates for 120 Countries. Economics: The OpenAccess, 2(1), 1-53. Retrieved from: http:// www.economics-ejournal.org/economics/ journalarticles/2007-9

\section{Schneider, F., \& Colin, W.}

The shadow economy. London: The Institute of Economic Affairs.

\section{Semboja, J.}

Why people pay taxes: The case of the development levy in Tanzania. Tanzania. World Development, 29(12), 2059-2074.

\section{Smith, D. J.}

The Annals of the American Academy

of Political and Social Science, 493(1), 83-99. DOI: https://doi. org/10.1177/0002716287493001007

\section{Stata}

http://www.stata.com/. Retrieved from: http://www.stata.com/: http://www.stata. com/manuals 13/rgmm.pdf

Tanzi, V.

1982

Fiscal disequilibrium in developing countries. World Development, Vol. 10, No. 12, 1069-1082. Retrieved from: https://doi. org/10.1016/0305-750X(82)90019-5

\section{Tokman, V.}

Wages and employment in international recessions: Recent Latin American experience. The Helen Kellogg Institute for International Studies. Working Paper 11. Retrieved from: https://kellogg. nd.edu/sites/default/files/old_files/ documents/011_0.pdf

\section{Tokman, V.}

Beyond regulation: The informal economy in Latin America (1st ed.). Boulder, CO: Lynne Rienner Publishers.

\section{Torgler, B., \& Schneider, F.}

The impact of tax morale and institutional quality on the shadow economy. The Institute for the Study of Labor Discussion Paper 254, 1-46.

\section{Voicu, Cristina}

Economics and "underground" economy theory. Theoretical and Applied Economics, Vol. XIX(7), 71-84

Wan Jie, S., Huam, T., Rasli, A., \& Thean Chye, L. causes. Business and Management Review, 1(2), 14-24. 


\section{bibliografía}

Webb, J.W., Bruton, G.D.,

Tihanyi, L., \& Ireland, R.D.

2013 Research on entrepreneurship in the informal economy: Framing a research agenda. Journal of Business Venturing,

1(17). DOI: 10.1016/j.jbusvent.2012.05.003

Webb, J.; Ireland, D. \&

Ketchen, D.

2014 Toward a greater understanding of entrepreneurship and strategy in the informal economy. Strategic

Entrepreneurship Journal, 8(1), 1-15.

\section{Wei, S.}

1997 Why is corruption so much more taxing than tax? Arbitrariness kills. The National Bureau of Economic Research. WP 6255, 1-25. Retrieved from: https://www.nber. org/papers/w6255

\section{Welter, F., Smallbone, D., \&}

Pobol, A.

2015 Entrepreneurial activity in the informal economy: a missing piece of the entrepreneurship jigsaw puzzle. Entrepreneurship \& Regional Development, 27(1), 292-306.

\section{Williams, B.}

1923 State morality in international relations. The American Political Science Review, 17(1), 17-33. Retrieved from: https://www. jstor.org/stable/pdf/1943790.pdf

\section{Williams, C.}

exploratory evaluation of competing perspectives. Industrial Relations, 70(4), 741-765.

Williams, C.

2015

Tackling entrepreneurship in the informal sector: an overview of the policy options. Journal of Developmental

Entrepreneurship, 20(1)

\section{Williams, C., Horodnic, I., \&}

\section{Burkinshaw, L.}

2016

Evaluating competing public policy

approaches towards the informal economy.

International Journal of Public, 29(4).

\section{Wilson, D. Tamar}

Introduction: Approaches to the informal economy. Urban Anthropology and Studies of Cultural Systems and World Economic, 40(3/4), 205-221.

Fecha de recepción: 03 de octubre de 2018 Fecha de aceptación: 15 de noviembre de 2018 